\title{
From structure topology to chemical composition. XXIII. Revision of the crystal structure and chemical formula of zvyaginite, $\mathrm{Na}_{2} \mathrm{ZnTiNb}_{2}\left(\mathrm{Si}_{2} \mathrm{O}_{7}\right)_{2} \mathrm{O}_{2}(\mathrm{OH})_{2}\left(\mathrm{H}_{2} \mathrm{O}\right)_{4}$, a seidozerite-supergroup mineral from the Lovozero alkaline massif, Kola peninsula, Russia
}

\author{
E. Sokolova ${ }^{1, *}$, A. Genovese ${ }^{2}$, A. Falqui ${ }^{2}$, F.C. Hawthorne ${ }^{1}$ And F. CÁmara ${ }^{3}$
}

1 Department of Geological Sciences, University of Manitoba, 125 Dysart Road, Winnipeg, MB, R3T 2N2 Canada

2 Biological and Environmental Sciences and Engineering Division, King Abdullah University of Science and Technology, Bldg. 2, Thuwal, 23955-6900, Saudi Arabia

3 Dipartimento di Scienze della Terra “Ardito Desio”, Università degli Studi di Milano, Via Mangiagalli 34, 20133, Milano, Italy

[Received 9 November 2016; Accepted 21 February 2017; Associate Editor: Peter Leverett]

\section{ABSTRACT}

The crystal structure and chemical formula of zvyaginite, ideally $\mathrm{Na}_{2} \mathrm{ZnTiNb}_{2}\left(\mathrm{Si}_{2} \mathrm{O}_{7}\right)_{2} \mathrm{O}_{2}(\mathrm{OH})_{2}\left(\mathrm{H}_{2} \mathrm{O}\right)_{4}$, a lamprophyllite-group mineral of the seidozerite supergroup from the type locality, Mt. Malyi Punkaruaiv, Lovozero alkaline massif, Kola Peninsula, Russia have been revised. The crystal structure was refined with a new origin in space group $C \overline{1}, a=10.769(2), b=14.276(3), c=12.101(2) \AA, \alpha=105.45(3), \beta=95.17(3)$, $\gamma=90.04(3)^{\circ}, V=1785.3(3.2) \AA^{3}, R_{1}=9.23 \%$. The electron-microprobe analysis gave the following empirical formula [calculated on $22(\mathrm{O}+\mathrm{F})$ ]: $\left(\mathrm{Na}_{0.75} \mathrm{Ca}_{0.09} \mathrm{~K}_{0.04} \square_{1.12}\right)_{\Sigma 2}\left(\mathrm{Na}_{1.12} \mathrm{Zn}_{0.88} \mathrm{Mn}_{0.17} \mathrm{Fe}_{0.04}^{2+} \square_{0.79}\right)_{\Sigma 3}$ $\left(\mathrm{Nb}_{1.68} \mathrm{Ti}_{1.25} \mathrm{Al}_{0.07}\right)_{\Sigma 3}\left(\mathrm{Si}_{4.03} \mathrm{O}_{14}\right) \mathrm{O}_{2}\left[(\mathrm{OH})_{1.11} \mathrm{~F}_{0.89}\right]_{\Sigma 2}\left(\mathrm{H}_{2} \mathrm{O}\right)_{4}, Z=4$. Electron-diffraction patterns have prominent streaking along $\mathrm{c}^{*}$ and HRTEM images show an intergrowth of crystalline zvyaginite with two distinct phases, both of which are partially amorphous. The crystal structure of zvyaginite is an array of TS (Titanium-Silicate) blocks connected via hydrogen bonds between $\mathrm{H}_{2} \mathrm{O}$ groups. The TS block consists of $\mathrm{HOH}$ sheets $\left(\mathrm{H}=\right.$ heteropolyhedral, $\mathrm{O}=$ octahedral) parallel to $(001)$. In the $\mathrm{O}$ sheet, the ${ }^{[6]} M^{\mathrm{O}}(1,4,5)$ sites are occupied mainly by $\mathrm{Ti}, \mathrm{Zn}$ and $\mathrm{Na}$ and the ${ }^{[6]} \mathrm{M}^{\mathrm{O}}(2,3)$ sites are occupied by $\mathrm{Na}$ at less than $50 \%$. In the $\mathrm{H}$ sheet, the ${ }^{[6]} M^{\mathrm{H}}(1,2)$ sites are occupied mainly by Nb and the ${ }^{[8]} A^{P}(1)$ and ${ }^{[8]} A^{P}(2)$ sites are occupied mainly by $\mathrm{Na}$ and $\square$. The $\mathrm{M}^{\mathrm{H}}$ and $\mathrm{A}^{P}$ polyhedra and $\mathrm{Si}_{2} \mathrm{O}_{7}$ groups constitute the $\mathrm{H}$ sheet. The ideal structural formula is $\mathrm{Na} \square \mathrm{Nb}_{2} \mathrm{NaZn} \square \mathrm{Ti}\left(\mathrm{Si}_{2} \mathrm{O}_{7}\right)_{2} \mathrm{O}_{2}(\mathrm{OH})_{2}\left(\mathrm{H}_{2} \mathrm{O}\right)_{4}$. Zvyaginite is a $\mathrm{Zn}$-bearing and Na-poor analogue of epistolite, ideally $(\mathrm{Na} \square) \mathrm{Nb}_{2} \mathrm{Na}_{3} \mathrm{Ti}\left(\mathrm{Si}_{2} \mathrm{O}_{7}\right)_{2} \mathrm{O}_{2}(\mathrm{OH})_{2}\left(\mathrm{H}_{2} \mathrm{O}\right)_{4}$. Epistolite and zvyaginite are related by the following substitution in the $\mathrm{O}$ sheet of the TS-block: $\left(\mathrm{Na}_{2}^{+}\right)_{\mathrm{epi}} \leftrightarrow \mathrm{Zn}_{\mathrm{zvy}}^{2+}+\square_{\mathrm{zvy}}$ The doubling of the $t_{1}$ and $t_{2}$ translations of zvyaginite relative to those of epistolite is due to the order of $\mathrm{Zn}$ and Na along $\mathbf{a}\left(\mathbf{t}_{\mathbf{1}}\right)$ and $\mathbf{b}\left(\mathbf{t}_{\mathbf{2}}\right)$ in the $\mathrm{O}$ sheet of zvyaginite.

KEYWoRDs: zvyaginite, crystal-structure refinement, HRTEM, electron diffraction, EMP analysis, chemical formula, lamprophyllite group, seidozerite supergroup, TS-block minerals, epistolite.

\section{Introduction}

*E-mail: elena_sokolova@umanitoba.ca https://doi.org/10.1180/minmag.2017.081.015
Zvyaginite was described from the Lovozero alkaline massif, Kola Peninsula, Russia by Pekov et al. (2014). They reported $a$ structural model for 
zvyaginite: space group $P \overline{1}, a=8.975(3), b=8.979$ (3), $c=12.135(4) \AA, \alpha=74.328(9), \beta=80.651(8)$, $\gamma=73.959(8)^{\circ}, V=900.8(6) \AA^{3}, R_{1}=15.9 \%$ and gave the simplified and idealized formulae as $\mathrm{NaZnNb}_{2} \mathrm{Ti}\left(\mathrm{Si}_{2} \mathrm{O}_{7}\right)_{2} \mathrm{O}(\mathrm{OH}, \mathrm{F})_{3}\left(\mathrm{H}_{2} \mathrm{O}\right)_{4+x}(x<1)$ and $\mathrm{NaZnNb}_{2} \mathrm{Ti}\left(\mathrm{Si}_{2} \mathrm{O}_{7}\right)_{2} \mathrm{O}(\mathrm{OH})_{3}\left(\mathrm{H}_{2} \mathrm{O}\right)_{4}, \quad Z=2$. They stated that zvyaginite and epistolite [ideally $(\mathrm{Na} \square) \mathrm{Nb}_{2} \mathrm{Na}_{3} \mathrm{Ti}_{(}\left(\mathrm{Si}_{2} \mathrm{O}_{7}\right)_{2} \mathrm{O}_{2}(\mathrm{OH})_{2}\left(\mathrm{H}_{2} \mathrm{O}\right)_{4}$, space group $P \overline{1}, a=5.460(1), b=7.170(1), c=12.041$ (2) A, $\alpha=103.63(3), \beta=96.01(3), \gamma=89.98(3)^{\circ}$, $V=455.4(5) \quad \AA^{3}, \quad R_{1}=9.8 \%$, Sokolova and Hawthorne (2004)] are topologically identical but differ in composition of the $\mathrm{O}$ sheet in the $\mathrm{HOH}$ block, where partial substitution of $\mathrm{Zn}^{2+}$ for $\mathrm{Na}^{+}$ occurs.

Zvyaginite and epistolite are lamprophyllitegroup minerals of the seidozerite supergroup (Sokolova and Cámara, 2017). The forty-five seidozerite-supergroup minerals have structures based on a TS-block ( $\mathrm{TS}=$ Titanium-Silicate). The TS-block consists of $\mathrm{HOH}$ sheets ( $\mathrm{H}=$ heteropolyhedral, $\mathrm{O}=$ octahedral $)$ and is characterized by a planar cell based on translation vectors, $t_{1}$ and $t_{2}$, with $t_{1} \approx 5.5$ and $t_{2} \approx 7 \AA$ and $t_{1} \wedge t_{2}$ close to $90^{\circ}$ (Sokolova, 2006; Sokolova and Cámara, 2013, 2016). The seidozerite-supergroup minerals are divided into four groups based on the content of $\mathrm{Ti}\left(+\mathrm{Nb}+\mathrm{Zr}+\mathrm{Fe}^{3+}+\mathrm{Mg}+\mathrm{Mn}\right)$, topology, chemical composition and stereochemistry of the TS block: rinkite group: $\mathrm{Ti}=1$ apfu (atoms per formula unit); bafertisite group: $\mathrm{Ti}=2$ apfu; lamprophyllite group: $\mathrm{Ti}=3$ apfu; murmanite group: $\mathrm{Ti}=4 \mathrm{apfu}$. The four groups correspond to Groups I, II, III and IV of Sokolova (2006).

Ideal structural formulae of the lamprophyllitegroup minerals with basic structures are given in Table 1. The lamprophyllite-group minerals with derivative structures: bornemanite (Cámara and Sokolova, 2007), nechelyustovite (Cámara and Sokolova, 2009), kazanskyite (Cámara et al., 2012) and saamite (Cámara et al., 2014) are not listed in the Table 1 as their structures are combination of structural fragments of basic structures of the lamprophyllite group [for the definition of basic and derivative structures see Sokolova and Cámara (2013)].

We considered the crystal structure of zvyaginite (Pekov et al., 2014) and found some unresolved problems: (1) Their empirical formula, $\mathrm{Na}_{1.24} \mathrm{~K}_{0.04} \mathrm{Ca}_{0.11} \mathrm{Mn}_{0.16} \mathrm{Al}_{0.06} \mathrm{Fe}_{0.03} \mathrm{Zn}_{0.96} \mathrm{Nb}_{1.66}$ $\mathrm{Ti}_{1.25}\left(\mathrm{Si}_{3.97} \mathrm{Al}_{0.03}\right)_{\Sigma 4} \mathrm{O}_{15.07}(\mathrm{OH})_{2.10} \mathrm{~F}_{0.83}\left(\mathrm{H}_{2} \mathrm{O}\right)_{4.64}$ (Table 2), gives $\left(\mathrm{H}_{2} \mathrm{O}\right)_{4.64}($ Lanions $=22.64 \mathrm{apfu})$ and the structure-refinement results give $\left(\mathrm{H}_{2} \mathrm{O}\right)_{4}$ ( anions $=22.00 \mathrm{apfu})$; hence there is significant disagreement between the chemical analysis and the structure-refinement results. (2) Aspects of the structure-refinement results raised questions about the correctness of the crystal-structure model: $(a)$ ratios of $U_{\text {eq }}$ for cations at the $N b(1)$ and $N b(2)$ sites and $Z n(1)$ and $Z n(2)$ sites were 3:1 and 1:3, respectively (Table 3); (b) Some interatomic distances were too long, e.g. ${ }^{[6]} \mathrm{Zn}(2)-\mathrm{O}(6)=$ $2.88 \AA$. (3) No quantitative relation between zvyaginite and epistolite was suggested.

We have re-examined zvyaginite as we wish to (1) relate epistolite and zvyaginite via the substitution mechanism in a quantitative way, and (2) understand the doubling of the $t_{1}$ and $t_{2}$ translations.

The forty-three TS-block structures of the seidozerite supergroup have unit cells based on translation vectors, $\mathbf{t}_{\mathbf{1}}$ and $\mathbf{t}_{\mathbf{2}}$ (Sokolova and Cámara, 2017), and only two structures, zvyaginite (Pekov et al., 2014) and vigrishinite, $\mathrm{Zn}_{2} \mathrm{Ti}_{4-x}\left(\mathrm{Si}_{2} \mathrm{O}_{7}\right)_{2} \mathrm{O}_{2-}$ $(\mathrm{OH}, \mathrm{F}, \mathrm{O})_{2}\left(\mathrm{H}_{2} \mathrm{O}, \mathrm{OH}, \square\right)_{4}, x<1$ (Pekov et al., 2013; Lykova et al., 2015), have unit cells based on the two diagonals of the planar cell: $\mathbf{a}_{\mathrm{zvy}}=-\mathbf{t}_{\mathbf{1}}+\mathbf{t}_{\mathbf{2}}$ and $\mathbf{b}_{\mathrm{zvy}}=\mathbf{t}_{\mathbf{1}}+\mathbf{t}_{\mathbf{2}}$. Such description of the crystal structure of zvyaginite complicates comparison of zvyaginite to epistolite (see the unit cell of epistolite above) and other TS-block structures.

Here, we report revision of the crystal structure of zvyaginite with a different origin and the refinement of the structure in space group $C \overline{1}$ for better comparison with all other TS-block structures; we will explain doubling of the $t_{1}$ and $t_{2}$ translations of zvyaginite relative to those translations in epistolite and revise the chemical formula of zvyaginite.

\section{Description of the sample}

\section{Sample description}

We obtained several fragments of a zvyaginite sample from an American mineral collector. This sample comes from the type locality, Mt. Malyi Punkaruaiv, Lovozero alkaline massif, Kola Peninsula, Russia (Pekov et al., 2014). From those fragments, we extracted five crystals for which we collected single-crystal X-ray data. Based on the unit-cell parameters, three crystals were identified as zvyaginite and two crystals as vigrishinite. The three crystals of zvyaginite are transparent colorless thin plates. In this paper, we report the structure solution and refinement results for crystal \#3; crystal \#2 of zvyaginite was used for the microprobe analysis. 
TABLE 1. Ideal structural formulae of the lamprophyllite-group minerals* (seidozerite supergroup) with basic structures.

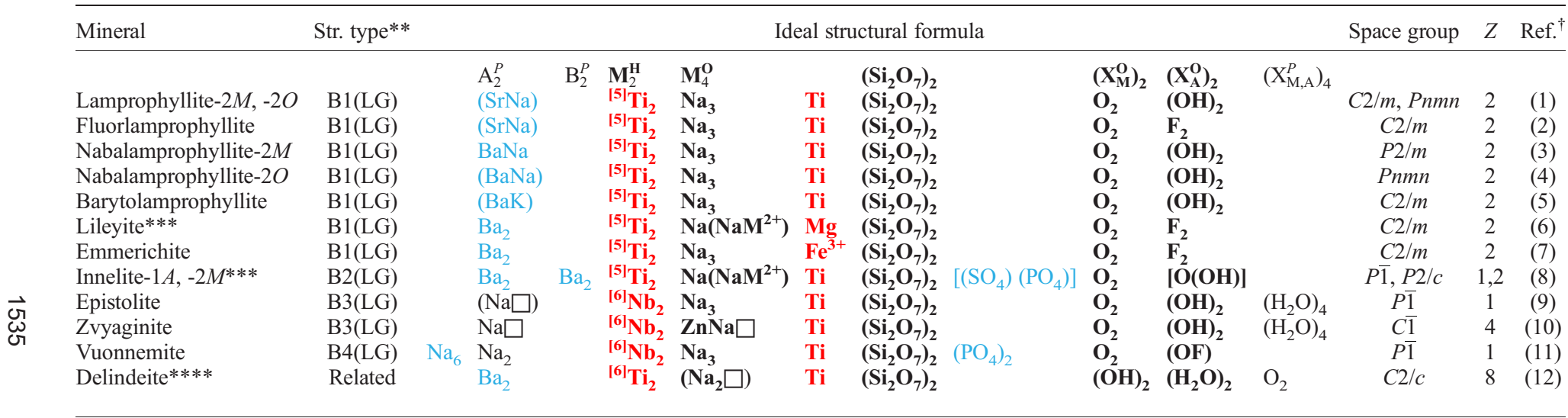

$* \mathrm{Ti}\left(+\mathrm{Nb}+\mathrm{Fe}^{3+}+\mathrm{Mg}\right)=3$ apfu.

**Structure type: B (basic) (Sokolova and Cámara, 2013); LG = Lamprophyllite group. The invariant core of the TS block, $\mathbf{M}_{2}^{\mathrm{H}} \mathbf{M}_{4}^{\mathrm{O}}\left(\mathbf{S i}_{2} \mathbf{O}_{7}\right)_{2} \mathbf{X}_{4}^{\mathbf{O}}$, is shown in bold; $\mathbf{M}^{\mathrm{O}}$ and $\mathrm{M}^{\mathrm{H}}=$ cations of the $\mathrm{O}$ and $\mathrm{H}$ sheets, $\mathrm{A}^{P}$ and $\mathrm{B}^{P}=$ cations at the peripheral $(P)$ sites; $\mathrm{X}_{4}^{\mathrm{O}}=$ anions of the $\mathrm{O}$ sheet not bonded to Si: $\mathrm{X}_{\mathrm{M}}^{\mathrm{O}}=$ anions at the common vertices of $3 \mathrm{M}^{\mathrm{O}}$ and $\mathrm{M}^{\mathrm{H}}$ polyhedra; $\mathrm{X}_{\mathrm{A}}^{\mathrm{O}}=$ anions at the common vertices of $3 \mathrm{M}^{\mathrm{O}}$ and $\mathrm{A}^{P}$ polyhedra (where $\mathrm{A}^{P}-\mathrm{X}_{\mathrm{A}}^{\mathrm{O}}<3 \AA$ ); $\mathrm{X}_{\mathrm{M}}^{P}$ and $\mathrm{X}_{\mathrm{A}}^{P}=$ apical anions of $\mathrm{M}^{\mathrm{H}}$ and $\mathrm{A}^{P}$ cations at the periphery of the TS block. In the lamprophyllite group, $\mathrm{A}^{P}$ and $\mathrm{B}^{P}$ cations (except for $\mathrm{Na}$ atoms which occur in the plane of the $\mathrm{H}$ sheet), plus $\mathrm{Na}$ atoms and $\left(\mathrm{PO}_{4}\right)$ groups (vuonnemite) and $\left[\left(\mathrm{PO}_{4}\right)\left(\mathrm{SO}_{4}\right)\right]$ groups (innelite) constitute the $\mathbf{I}$ block (shown in turquoise colour).

$* * * \mathrm{M}^{2+}=\mathrm{Fe}^{2+}, \mathrm{Ca}, \mathrm{Mn}$ (lileyite); $\mathrm{M}^{2+}=\mathrm{Mn}, \mathrm{Fe}^{2+}, \mathrm{Mg}, \mathrm{Ca}$ (innelite)

****Due to the $\mathrm{Na}-\mathrm{H}_{2} \mathrm{O}$ disorder in the $\mathrm{O}$ sheet, the TS block in delindeite retains linkage 1 but exhibits stereochemistry of the rinkite group.

${ }^{\dagger}$ The most recent reference on the structure: (1) Krivovichev et al. (2003); (2) Andrade et al. (2017); (3) Rastsvetaeva and Chukanov (1999); (4) Sokolova and Hawthorne (2008); (5) Sokolova and Cámara (2008); (6) Chukanov et al. (2012); (7) Aksenov et al. (2014); (8) Sokolova et al. (2011); (9) Sokolova and Hawthorne (2004); (10) this work; (11) Ercit et al. (1998); (12) Sokolova and Cámara (2007). 


\section{E. SOKOLOVA ETAL.}

TABLE 2. Chemical composition and unit formula for zvyaginite.

\begin{tabular}{|c|c|c|c|c|c|}
\hline \multicolumn{4}{|c|}{ Chemical composition* (wt.\%) } & \multicolumn{2}{|c|}{ Unit formula $(\mathrm{apfu})^{* * *}$} \\
\hline & This work & Pekov et al. (2014) & & This work & Pekov et al. (2014) \\
\hline $\mathrm{Nb}_{2} \mathrm{O}_{5}$ & 27.33 & 27.72 & $\mathrm{Nb}$ & 1.68 & 1.66 \\
\hline $\mathrm{TiO}_{2}$ & 12.23 & 12.33 & $\mathrm{Ti}$ & 1.25 & 1.25 \\
\hline $\mathrm{SiO}_{2}^{2}$ & 29.63 & 29.42 & $\mathrm{Si}$ & 4.03 & 3.97 \\
\hline $\mathrm{Al}_{2} \mathrm{O}_{3}$ & 0.42 & 0.19 & $\mathrm{Al}$ & 0.07 & 0.03 \\
\hline $\mathrm{ZnO}$ & 8.71 & 9.61 & $\mathrm{Zn}$ & 0.88 & 0.96 \\
\hline $\mathrm{FeO}$ & 0.34 & 0.24 & $\mathrm{Fe}^{2+}$ & 0.04 & 0.03 \\
\hline $\mathrm{MnO}$ & 1.44 & 1.36 & $\mathrm{Mn}$ & 0.17 & 0.16 \\
\hline $\mathrm{CaO}$ & 0.59 & 0.77 & $\mathrm{Ca}$ & 0.09 & 0.11 \\
\hline $\mathrm{K}_{2} \mathrm{O}$ & 0.25 & 0.22 & $\mathrm{~K}$ & 0.04 & 0.04 \\
\hline $\mathrm{Na}_{2} \mathrm{O}$ & 7.10 & 4.74 & $\mathrm{Na}$ & 1.87 & 1.24 \\
\hline $\mathrm{F}^{2}$ & 2.06 & 1.94 & F & 0.89 & 0.83 \\
\hline $\mathrm{H}_{2} \mathrm{O}$ & $10.04 *$ & $12.65 * *$ & $\mathrm{OH}$ & 1.11 & 2.10 \\
\hline $\mathrm{O}=\mathrm{F}$ & -0.87 & -0.82 & $\mathrm{H}_{2} \mathrm{O}$ & 4.00 & 4.64 \\
\hline \multirow[t]{2}{*}{ Total } & $\overline{99.27}$ & $\overline{99.87}$ & $\sum$ cations & 10.12 & 9.45 \\
\hline & & & $\Sigma$ (anions, $\mathrm{H}_{2} \mathrm{O}$ gr.) & 22.00 & 22.64 \\
\hline
\end{tabular}

*Calculated from crystal-structure refinement.

**Modified Penfield method.

***Formula calculated on: (1) this work: $22(\mathrm{O}+\mathrm{F})$ apfu, with $\mathrm{OH}+\mathrm{F}=2$ pfu and $\mathrm{H}_{2} \mathrm{O}=4 \mathrm{pfu}$; and

(2) Pekov et al. (2014): $\mathrm{Si}+\mathrm{Al}=8$ apfu.

\section{Transmission electron microscopy (TEM)}

We prepared three different zvyaginite samples 2-3 $\mathrm{mm}$ in width for transmission electron microscopy (TEM) by selecting crystals with evident $\{001\}$ cleavage and well-developed lateral crystal faces, useful for approximate pre-orientation along the main lattice vectors. Each pre-oriented crystal was sandwiched and glued between two graphite supports, and after that underwent both mechanical and ion polishing to obtain a thin and electrontransparent section.

The high-resolution TEM (HRTEM) images and electron-diffraction (ED) patterns were acquired using an FEI Titan Cubed 60-300 electron microscope equipped with a high-brightness field emission gun, a Wien-type monochromator, a spherical-aberration (Cs) corrector for the objective lens system allowing atomic spatial resolution $(0.9 \AA)$, a Gatan K2-IS direct-detection camera

TABLE 3. Refined site-scattering, assigned site-populations and $U_{\text {eq }}$ for cation sites (excluding $S i$ ) in zvyaginite after Pekov et al. (2014).

\begin{tabular}{lcccc}
\hline Site & Mult. $^{*}$ & Refined site-scattering (epfu) & Assigned site-population (apfu) & $U_{\text {eq }}\left(\AA^{2}\right)$ \\
\hline$N b(1)$ & 1.0 & 32.6 & $\mathrm{Nb}_{0.56} \mathrm{Ti}_{0.44}$ & 0.029 \\
$N b(2)$ & 1.0 & 41.0 & $\mathrm{Nb}$ & 0.010 \\
$T i(1)$ & 0.5 & 10.0 & $\mathrm{Ti}_{0.455} \square_{0.045}$ & 0.014 \\
$T i(2)$ & 0.5 & 11.1 & $\mathrm{Ti}_{0.505}$ & 0.016 \\
$Z n(1)$ & 1.0 & 22.8 & $\mathrm{Zn}_{0.58} \square_{0.42}$ & 0.007 \\
$Z n(2)$ & 1.0 & 24.8 & $\mathrm{Zn}_{0.62} \square_{0.38}$ & 0.023 \\
$N a(1)$ & 1.0 & 5.1 & $\mathrm{Na}_{0.46} \square_{0.54}$ & 0.023 \\
$N a(2)$ & 1.0 & 5.4 & $\mathrm{Na}_{0.49} \square_{0.51}$ & 0.026 \\
$N a(3)$ & 1.0 & 5.3 & $\mathrm{Na}_{0.48} \square_{0.52}$ & 0.027 \\
& & & & \\
\hline
\end{tabular}

* Multiplicity, space group $P \overline{1}$. 
with a 14.2-megapixel sensor able to sample images at rates up to 1600 full frames per second, and a post-column Gatan Image Filter (GIF) Tridiem 865.

All thin crystalline sections were coated with a thin layer of carbon a few nanometres thick to prevent local charging and dissipate heat during the TEM observations. The HRTEM imaging was done at $300 \mathrm{kV}$ tuning the $\mathrm{Cs}$ corrector with a negative $\mathrm{Cs}$ value $(-15 \mu \mathrm{m})$ to maximize spatial resolution and the contrast of the atomic columns, respectively, in low-dose conditions $\left(\sim 50 e^{-} / \AA^{2} \mathrm{~s}\right)$ to limit beam damage of the crystals, and using the directdetection camera to maximize the signal-to-noise ratio. The Cs corrector allows collection of a vast extension of lattice frequencies - up to $11.1 \mathrm{~nm}^{-1}$ in reciprocal units - without reversals in the contrast transfer function (CTF), and extending the final resolution up to the information limit of the lens system. This advantage eliminates the need of objective apertures for HRTEM imaging. In particular, during the TEM analysis, the three samples were oriented correctly along the zone axes.

Zvyaginite thin sections exhibited feeble electronbeam damage despite the precautions taken for a correct and safe TEM imaging.

The TEM investigation of the samples revealed a band structure characterized by the alternation of defect-free bands and defective domains along the $<001>$ direction. The defect-bearing bands, in turn, exhibited interleaving of $\{001\}$ lamellae extended many hundreds of nanometres along the $<110>$ direction, a few tens of nanometres along the $<001>$ but very few tens of nanometres along the $<\overline{1} 10>$ direction.

\section{The [001] projection}

HRTEM imaging along the $[00 \overline{1}]$ zone axis showed large undisturbed regions of the crystal. The corresponding ED patterns contained $\mathbf{g}(\overline{1} 10)$ and $\mathbf{g}(110)$ reciprocal crystal directions forming an angle of $104^{\circ}$, but with no evidence of twinning or apparent streaking along these directions (Fig. 1a). The $[00 \overline{1}]$ diffraction features may be a direct indication of such a lamellar structure for zvyaginite, where $\{001\}$ defect-rich domains are separated by extended and undisturbed crystal regions.

The lattice geometry characterization, extrapolated from Fourier-transform (FT) pattern analysis and direct-space imaging, shows planar (2D) cells with rhombic symmetry forming angles of $\sim 76^{\circ}$ and $\sim 104^{\circ}$. The corresponding interplanar spacings are $d(\overline{1} 10) \approx 8.6 \AA$ and $d(110) \approx 8.3 \AA$, in accord with the triclinic structure of zvyaginite described by the $\mathbf{t}_{\mathbf{1}}$ and $\mathbf{t}_{\mathbf{2}}$ translational vectors and the space group $C \overline{1}$ (Fig. 1b).

\section{The [110] projection}

Similarly, HRTEM investigation of crystal sections along the [110] zone axis also shows the presence of large and undisturbed domains. The corresponding ED patterns show apparent $\mathbf{g}(\overline{1} 10)$ and $\mathbf{g}(00 \overline{1})$ reciprocal axes forming an angle of $95^{\circ}$ (Fig. 2a). Again, there were no indications of any twinning or streaking along these main lattice directions, confirming the limited lateral width of the defective lamellae along the $<\overline{1} 10>$ direction. The highmagnification HRTEM image displays 2D lattice cells with a quasi-rhombic geometry and internal angles of $\sim 85^{\circ}$ and $\sim 95^{\circ}$, with $d(\overline{1} 10) \approx 8.6 \AA$ and $d(00 \overline{1}) \approx 11.5 \AA$ (Fig. $2 b$ ).

\section{The [110] projection}

The HRTEM images of zvyaginite along the [110] zone axis show a lamellar structure interleaved along the $<001>$ direction. There are three different types of lamellae (type-I, type-II, type-III), on the basis of their electron contrast, crystallinity and internal structure, which alternate along the $<001>$ direction. Type-I lamellae exhibit an even electron contrast and high-to-moderate crystallinity with a weak tendency to be amorphized on exposure to the electron-beam. These lamellae are directly related to the undisturbed zvyaginite structure. Type-II lamellae show a lighter electron contrast and scarce crystallinity that amorphizes completely during observation. Type-III lamellae display an electron contrast similar to type-I, but intermediate crystallinity due to a highly defective structure characterized by wavy and ill-defined lattice planes, which become amorphous under the beam (Fig. 3a).

The [110] ED patterns of zvyaginite thin sections display intense streaking along and parallel to the $<001>$ direction, which can be ascribed to pervasive interleaving of $\{001\}$ domains and their defective internal structure mainly due to the disorder in the heteropolyhedral sheets, which generate lamellae of different thickness and ion distribution. Electron diffraction indexing allowed straightforward identification of the $\mathbf{g}(110)$ and $\mathbf{g}(00 \overline{1})$ reciprocal axes, forming an angle of $104^{\circ}$, and the correct orientation of the lamellae with respect to the lattice vectors (Fig. 3a). The distribution of the three types of lamellae was not the same across the crystals: type-I and type-II 

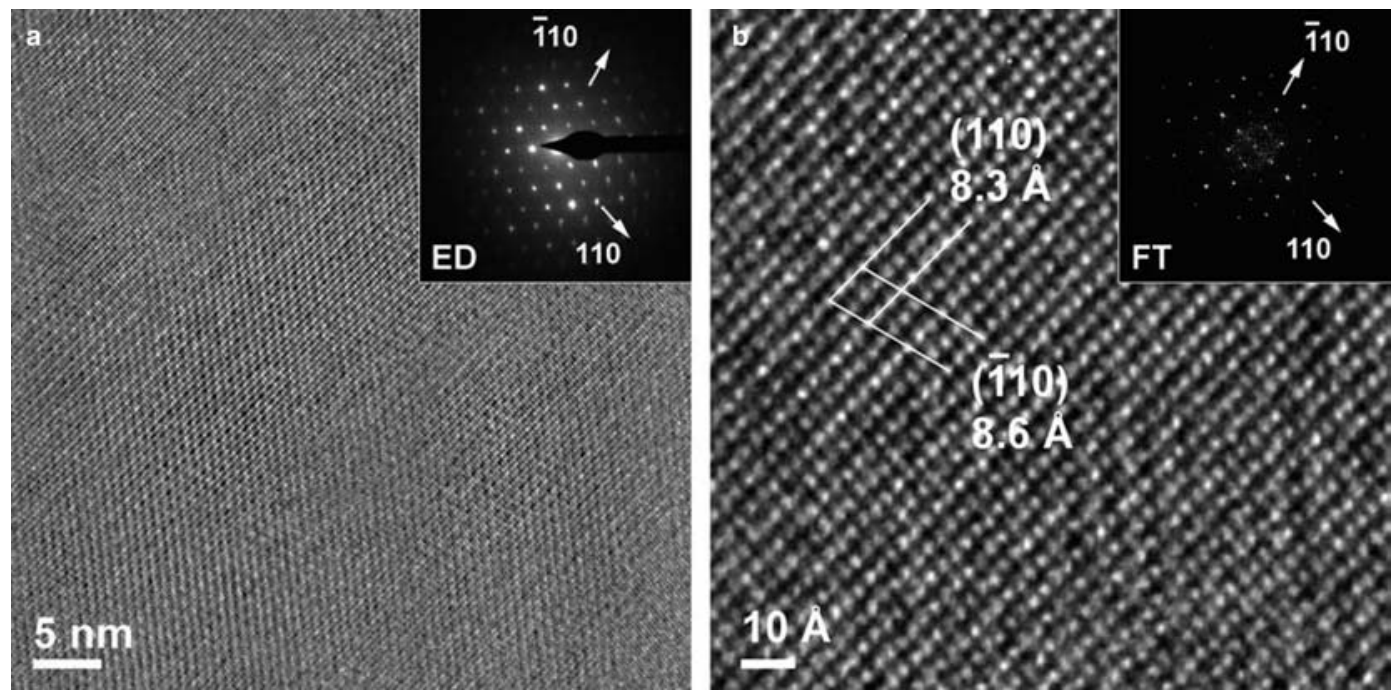

FIG. 1. HRTEM images of zvyaginite along the $[00 \overline{1}]$ zone axis. (a) Intermediate magnification of an undisturbed region a few hundred nanometres across with its corresponding ED pattern showing $\mathbf{g}(\overline{110})$ and $\mathbf{g}(110)$ with no streaking. (b) Higher magnification showing a rhombic 2D lattice cell, as confirmed by the corresponding FT (inset); $d(\overline{1} 10) \approx 8.6 \AA$ and $d(110) \approx 8.3 \AA$.

lamellae are ubiquitous, but type-III are sporadic. The typical HRTEM image of the [110] zone is shown in Fig. 3b, where only lamellae of type-I (darker electron contrast) and type-II (lighter electron contrast) can be identified.
Careful investigation of type-I lamellae revealed slight differences in their fine structure. A [1110] HRTEM image of the undisturbed fine structure of zvyaginite is displayed in Fig. $3 c$, where the uninterrupted lattice planes $d(110)(\approx 8.3 \AA)$ and
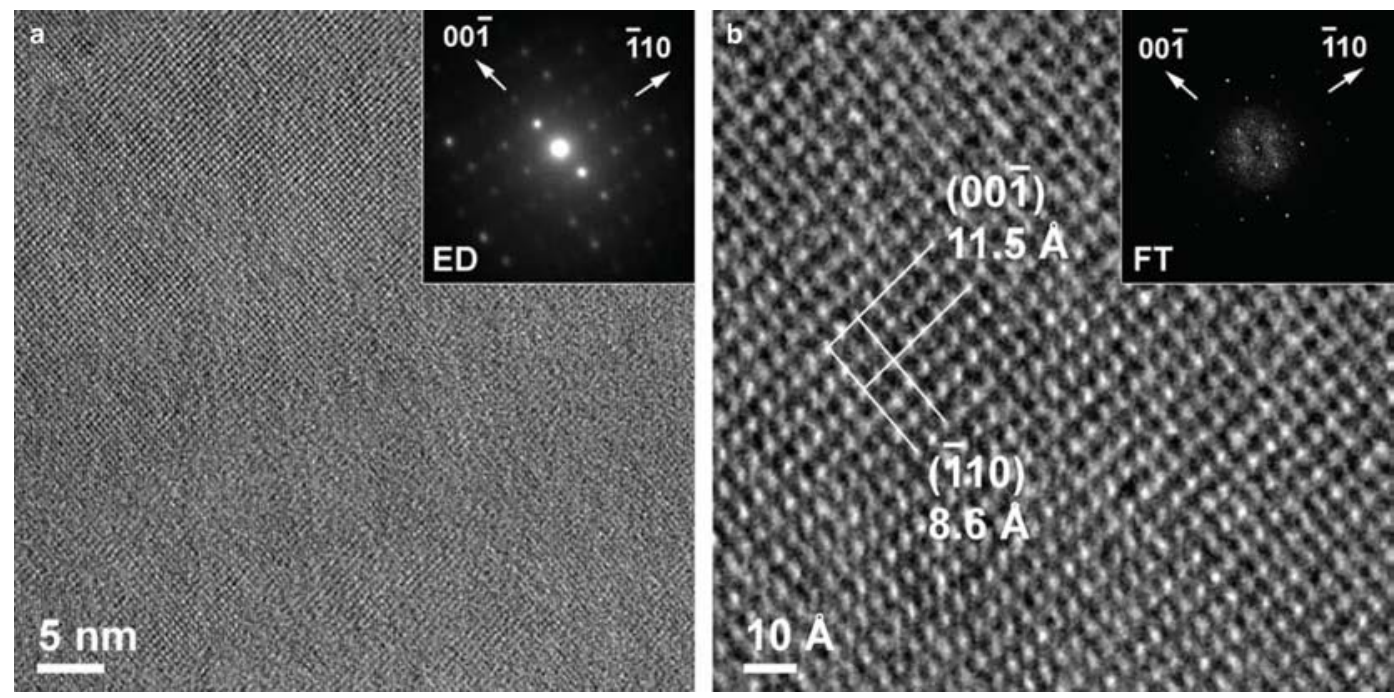

FIG. 2. HRTEM images of zvyaginite along the [110] zone axis. (a) Intermediate magnification of an undisturbed region a few hundred nanometres across with its corresponding ED pattern showing $\mathbf{g}(\overline{1} 10)$ and $\mathbf{g}(00 \overline{1})$ with no streaking. (b) Higher magnification showing quasi-rhombic 2D lattice cell, as shown in the corresponding FT (inset); $d(\overline{1} 10) \approx 8.6 \AA$ and $d(00 \overline{1}) \approx 11.5 \AA$. 

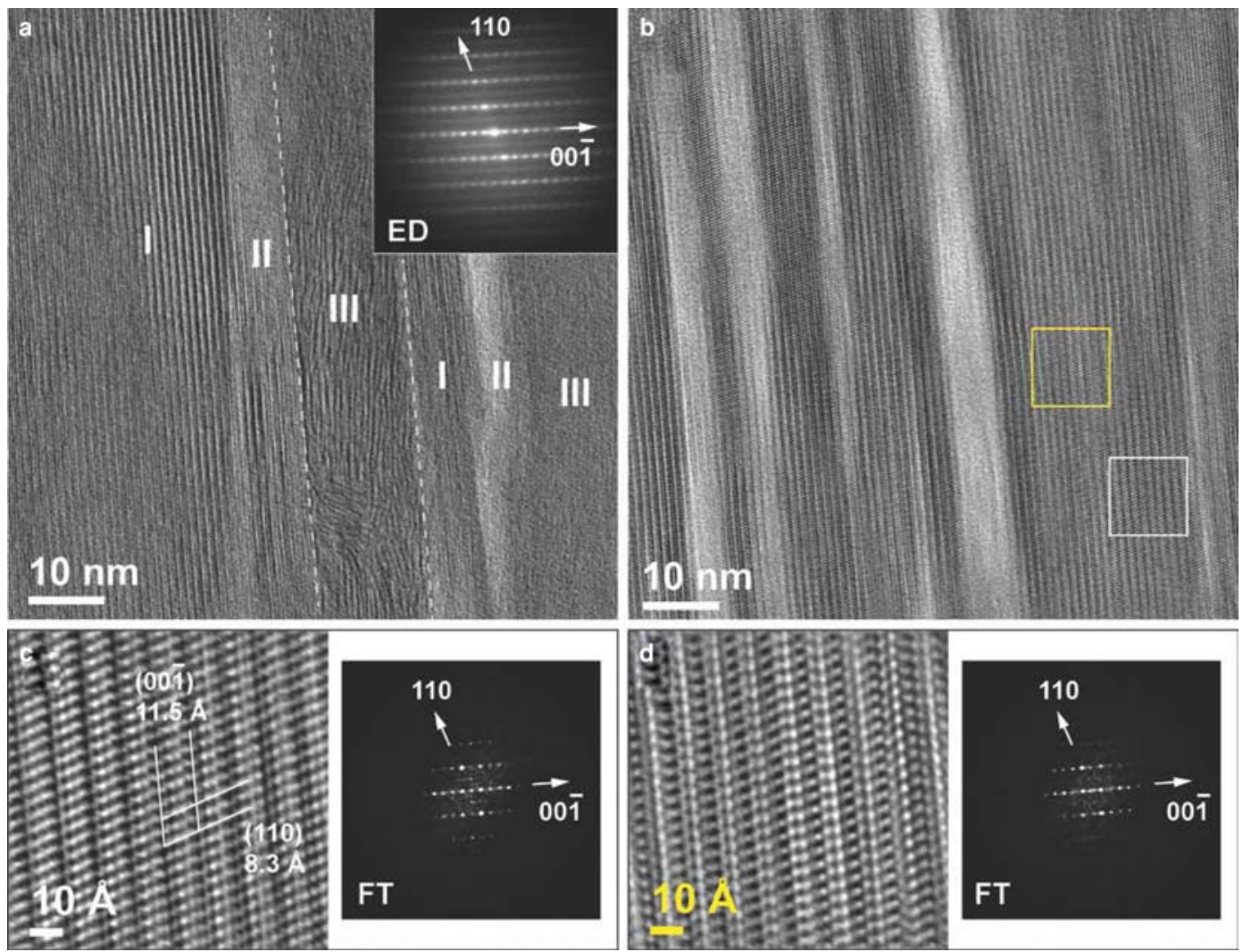

FIG. 3. HRTEM images of zvyaginite along the [110] zone axis. (a) HRTEM image at intermediate magnification showing the $[00 \overline{1}]$ stacking of the three types of lamellae (I, II, III); note the corresponding ED pattern (inset) showing $\mathbf{g}(110)$ and $\mathbf{g}(00 \overline{1})$ and intense streaking parallel to the $[00 \overline{1}]$ direction. (b) HRTEM image at intermediate magnification showing typical interleaving of type-I and type-II lamellae; white and yellow squares depict two regions of interest (ROI) within type-I lamella. (c) HRTEM detail of white ROI in (b), and corresponding FT (inset) showing the uninterrupted crystal structure with rhombic-shaped $2 \mathrm{D}$ lattice cell with $d(110) \approx 8.3 \AA$ and $d(00 \overline{1}) \approx 11.5 \AA$. (d) HRTEM detail of yellow ROI in $(b)$, and corresponding FT (inset) showing a subtle change in the type-I lamella.

$d(00 \overline{1})(\approx 11.5 \AA)$ form rhombic-shaped 2D lattice cells with internal angles of $\sim 76^{\circ}$ and $\sim 104^{\circ}$, as expected. However, a few tens of nanometres from the undisturbed regions, the fine structure of type-I lamellae exhibits a small but noticeable change that may be correlated with the stacking of layers with a slightly different structure along the $<001>$ direction (Fig. 3d).

\section{Chemical analysis}

The crystal of zvyaginite used for the microprobe analysis is a plate $(0.08 \mathrm{~mm} \times 0.05 \mathrm{~mm} \times 0.005 \mathrm{~mm})$ where the edges have some curvature, and hence the data were collected in the central flat part of the plate.
The crystal was analysed with a Cameca SX-100 electron-microprobe operating in wavelengthdispersion mode with an accelerating voltage of $15 \mathrm{kV}$, a specimen current of $5 \mathrm{nA}$, a beam size of $20 \mu \mathrm{m}$ and count times on peak and background of 20 and $10 \mathrm{~s}$, respectively. The following standards were used: $\mathrm{Si}, \mathrm{Ca}$ : diopside; $\mathrm{Al}$ : andalusite; $\mathrm{F}$ : fluoribeckite; $\mathrm{Na}$ : albite; $\mathrm{Nb}$ : $\mathrm{Ba}_{2} \mathrm{NaNb}_{5} \mathrm{O}_{15}$; Fe: fayalite; Mn: spessartine; Zn: gahnite; Ti: titanite; K: orthoclase. $\mathrm{Ta}, \mathrm{Zr}, \mathrm{Mg}$ and $\mathrm{Sr}$ were sought but not detected. Data were reduced using the $\varphi(\rho Z)$ procedure of Pouchou and Pichoir (1985). For $\mathrm{Na}_{2} \mathrm{O}, 7.10$ wt.\% was achieved only for the first point and further attempts to analyse this grain again resulted in lower values for $\mathrm{Na}_{2} \mathrm{O}, \sim 6.34$ 6.94, indicating diffusion of $\mathrm{Na}$ away from the 


\section{E. SOKOLOVA ETAL.}

excitation volume of the electron beam. To calculate the empirical formula of zvyaginite in accord with the structure results, we used the $\mathrm{Na}_{2} \mathrm{O}$ value from point 1 . The chemical composition of zvyaginite is the mean of three determinations and is given in Table 2. Our chemical analysis of zvyaginite is close to that of Pekov et al. (2014) except for the higher $\mathrm{Na}_{2} \mathrm{O}$ content 7.10 vs. $4.74 \mathrm{wt} . \%$ (Pekov et al., 2014) (Table 2).

The empirical formula of zvyaginite was calculated on the basis of $22(\mathrm{O}+\mathrm{F})$ with two constraints derived from the crystal-structure refinement: (1)

TABLE 4. Miscellaneous refinement data for zvyaginite.

\begin{tabular}{|c|c|c|}
\hline & $(1)^{*}$ & $(2)^{* *}$ \\
\hline$a(\AA)$ & $10.769(2)$ & $8.944(6)$ \\
\hline$b$ & $14.276(3)$ & $8.938(5)$ \\
\hline$c$ & $12.101(2)$ & $12.101(8)$ \\
\hline$\alpha\left({ }^{\circ}\right)$ & $105.45(3)$ & $74.516(9)$ \\
\hline$\beta$ & $95.17(3)$ & $80.89(1)$ \\
\hline$\gamma$ & $90.04(3)$ & $74.07(1)$ \\
\hline$V\left(\AA^{3}\right)$ & $1785.3(3.2)$ & $892.7(1.6)$ \\
\hline Refl. $\left(I_{\mathrm{o}}>10 \sigma I\right)$ & 6840 & 6840 \\
\hline Space group & $C \overline{1}$ & $P \overline{1}$ \\
\hline$Z$ & 4 & 2 \\
\hline Absorption coefficient $\left(\mathrm{mm}^{-1}\right)$ & 3.40 & 1.70 \\
\hline$F(000)$ & 1578.0 & 789.0 \\
\hline$D_{\text {calc. }}\left(\mathrm{g} / \mathrm{cm}^{3}\right)$ & 3.02 & 3.02 \\
\hline Crystal size $(\mathrm{mm})$ & \multirow{2}{*}{\multicolumn{2}{|c|}{$\begin{array}{c}0.120 \times 0.060 \times 0.004 \\
\text { MoKo/graphite }\end{array}$}} \\
\hline Radiation/monochromator & & \\
\hline $2 \theta_{\max }\left({ }^{\circ}\right)$ & 60.12 & 60.12 \\
\hline$R($ int $)(\%)$ & 4.57 & 4.57 \\
\hline Reflections collected & 10,111 & 10,111 \\
\hline Independent reflections & 5101 & 5101 \\
\hline Reflections with $F_{\mathrm{o}}>4 \sigma F$ & 3586 & 3587 \\
\hline Refinement method & \multicolumn{2}{|c|}{$\begin{array}{l}\text { Full-matrix least squares } \\
\text { on } F^{2} \text {, fixed weights } \\
\text { proportional to } 1 / \sigma F_{\mathrm{o}}^{2}\end{array}$} \\
\hline Final $R_{\text {(obs) }}(\%)$ & & \\
\hline$R_{1}\left[F_{\mathrm{o}}>4 \sigma F\right]$ & 9.23 & 9.42 \\
\hline$R_{1}$ (all data) & 12.27 & 12.49 \\
\hline$w R_{2}$ & 23.68 & 24.32 \\
\hline Goodness of fit on $F^{2}$ & 1.089 & 1.083 \\
\hline
\end{tabular}

* The two unit-cell parameters of zvyaginite (1) are doubled where compared to those of epistolite: $a_{\mathrm{zvy}}=$ $2 a_{\text {epi }} ; b_{\text {zvy }}=2 b_{\text {epi }}$.

**The unit cell (2), space group $P \overline{1}$, is a reduced unit cell equivalent to the unit cell of zvyaginite of Pekov et al. (2014): $a=8.975(3), b=8.979(3), c=12.135(4) \AA$, $\alpha=74.328(9), \beta=80.651(8), \gamma=73.959(8)^{\circ}, V=900.8(6) \AA^{3}$. To transform the unit cell (2) into the unit cell (1) we use matrix ( $\overline{1} 1011000 \overline{1})$.
$\mathrm{OH}+\mathrm{F}=2$ pfu and (2) $\mathrm{H}_{2} \mathrm{O}=4$ pfu, giving $\left(\mathrm{Na}_{0.75} \mathrm{Ca}_{0.09} \mathrm{~K}_{0.04} \square_{1.12}\right)_{\Sigma 2}\left(\mathrm{Na}_{1.12} \mathrm{Zn}_{0.88} \mathrm{Mn}_{0.17}\right.$ $\left.\mathrm{Fe}_{0.04}^{2+} \square_{0.79}\right)_{\Sigma 3}\left(\mathrm{Nb}_{1.68} \mathrm{Ti}_{1.25} \mathrm{Al}_{0.07}\right)_{\Sigma 3} \quad\left(\mathrm{Si}_{4.03} \mathrm{O}_{14}\right)$ $\mathrm{O}_{2}\left[(\mathrm{OH})_{1.11} \mathrm{~F}_{0.89}\right]_{\Sigma 2}\left(\mathrm{H}_{2} \mathrm{O}\right)_{4}, \quad Z=4$. The ideal formula is $\mathrm{Na}_{2} \mathrm{ZnTiNb}_{2}\left(\mathrm{Si}_{2} \mathrm{O}_{7}\right)_{2} \mathrm{O}_{2}(\mathrm{OH})_{2}\left(\mathrm{H}_{2} \mathrm{O}\right)_{4}$.

\section{X-ray data collection and structure refinement}

We collected single-crystal X-ray data for zvyaginite crystals \#1, \#2 and \#3 and refined their crystal structures using atom coordinates of Pekov et al. (2014) to $R_{1}=15.78,14.28$ and $12.69 \%$, respectively. However, we encountered the same problems that we outlined above: the ratios of $U_{\text {eq }}$ for cations at the $N b(1)$ and $N b(2)$ sites and $Z n(1)$ and $Z n(2)$ sites were $3: 1$ and 1:3, respectively; ${ }^{[6]} \mathrm{Zn}(2)-\mathrm{O}(6)=2.88 \AA$. We used direct methods to find another solution and were able to refine the structure in space group $P \overline{1}$ to $R_{1}=9.42 \%$ (Table 4 ). Our new structure had a different origin when compared to the structure of Pekov et al. (2014) and was free of the problems outlined above. However we felt that the refinement of the structure of zvyaginite using a unit cell based on $t_{1}$ and $t_{2}$ translations would give us an opportunity to better understand the relation between zvyaginite and all other TS-block structures, especially epistolite. We used the transformation matrix ( $(11011000 \overline{1})$ to go from the unit cell of Pekov et al. (2014) to the unit cell based on $t_{1}$ and $t_{2}$ translations, space group $C \overline{1}$ (Table 4). The unit cell of Pekov et al. (2014) is a reduced cell with regard to the unit cell with space group $C \overline{1}$. Below we give details of data collection and structure refinement using the $C \overline{1}$ setting.

$\mathrm{X}$-ray data for zvyaginite were collected for crystal \#3 with a Bruker APEX II ULTRA threecircle diffractometer equipped with a rotatinganode generator $(\mathrm{Mo} K \alpha)$, multilayer optics and an APEX II 4K CCD detector. Details of data collection and structure refinement are given in Table 4 . The intensities of reflections with $-14 \leq$ $h \leq 15,-19 \leq k \leq 19,-16 \leq l \leq 16$ were collected with a frame width of $0.5^{\circ}$ and a frame time of $18 \mathrm{~s}$, and an empirical absorption correction (SADABS, Sheldrick, 2008) was applied. The crystal structure of zvyaginite was solved and refined in space group $C \overline{1}$ with the Bruker SHELXTL Version 5.1 (SADABS, Sheldrick, 2008). The crystal structure of zvyaginite was refined to $R_{1}=9.23 \%$ (Table 4 ). The occupancies of nine cation sites were refined with the following scattering curves: $M^{\mathrm{H}}(1,2)$ and $A^{P}(1,2)$ sites: $\mathrm{Nb}$ and $\mathrm{Na} ; M^{\mathrm{O}}(1)$ site: $\mathrm{Ti} ; M^{\mathrm{O}}(2)$, $M^{\mathrm{O}}(3)$ and $M^{\mathrm{O}}(5)$ sites: $\mathrm{Na} ; M^{\mathrm{O}}(4)$ site: $\mathrm{Zn}$. We 
TABLE 5. Atom coordinates and equivalent displacement parameters $\left(\AA^{2}\right)$ for zvyaginite.

\begin{tabular}{|c|c|c|c|c|c|}
\hline Atom & Site occ. $(\%)$ & $x$ & $y$ & $z$ & $U_{\text {eq }}$ \\
\hline $\mathrm{M}^{\mathrm{H}}(1)$ & 100 & $0.89893(9)$ & $0.18624(8)$ & $0.74159(10)$ & $0.0196(4)$ \\
\hline $\mathrm{M}^{\mathrm{H}}(2)$ & 100 & $0.39831(9)$ & $0.19855(8)$ & $0.74170(10)$ & $0.0183(4)$ \\
\hline $\mathrm{M}^{\mathrm{O}}(1)$ & 100 & $0.25277(19)$ & $0.00006(14)$ & $0.0013(2)$ & $0.0223(7)$ \\
\hline $\mathrm{M}^{\mathrm{O}}(2)$ & 48 & $1 / 4$ & $1 / 4$ & 0 & $0.031(5)$ \\
\hline $\mathrm{M}^{\mathrm{O}}(3)$ & 42 & $3 / 4$ & $1 / 4$ & 0 & $0.034(5)$ \\
\hline $\mathrm{M}^{\mathrm{O}}(4)$ & 97 & $0.00009(13)$ & $0.11964(10)$ & $0.00036(15)$ & $0.0199(5)$ \\
\hline $\mathrm{M}^{\mathrm{O}}(5)$ & 79 & $0.4999(4)$ & $0.1296(3)$ & $-0.0001(3)$ & $0.0346(14)$ \\
\hline $\mathrm{A}^{P}(1)$ & 64 & $0.3928(5)$ & $0.9354(5)$ & $0.7030(6)$ & $0.027(2)$ \\
\hline $\mathrm{A}^{P}(2)$ & 24 & $0.108(2)$ & $0.072(3)$ & $0.300(3)$ & $0.101(19)$ \\
\hline $\mathrm{Si}(1)$ & 100 & $0.1508(3)$ & $0.8427(2)$ & $0.7663(3)$ & $0.0193(7)$ \\
\hline $\mathrm{Si}(2)$ & 100 & $0.1502(3)$ & $0.0534(2)$ & $0.7667(3)$ & $0.0195(7)$ \\
\hline $\mathrm{Si}(3)$ & 100 & $0.1504(3)$ & $0.3427(2)$ & $0.7637(3)$ & $0.0201(7)$ \\
\hline $\mathrm{Si}(4)$ & 100 & $0.3497(3)$ & $0.9475(2)$ & $0.2373(3)$ & $0.0204(7)$ \\
\hline $\mathrm{O}(1)$ & 100 & $0.5235(7)$ & $0.2853(6)$ & $0.7115(8)$ & $0.0303(19)$ \\
\hline $\mathrm{O}(2)$ & 100 & $0.7706(8)$ & $0.2784(7)$ & $0.7273(9)$ & $0.037(2)$ \\
\hline $\mathrm{O}(3)$ & 100 & $0.1555(7)$ & $0.8798(6)$ & $0.9056(7)$ & $0.0254(17)$ \\
\hline $\mathrm{O}(4)$ & 100 & $0.1602(8)$ & $0.9367(5)$ & $0.7140(8)$ & $0.0281(18)$ \\
\hline $\mathrm{O}(5)$ & 100 & $0.2696(8)$ & $0.0994(7)$ & $0.7291(9)$ & $0.037(2)$ \\
\hline $\mathrm{O}(6)$ & 100 & $0.0225(8)$ & $0.0841(7)$ & $0.7131(9)$ & $0.037(2)$ \\
\hline $\mathrm{O}(7)$ & 100 & $0.1548(7)$ & $0.0778(6)$ & $0.9057(8)$ & $0.0257(17)$ \\
\hline $\mathrm{O}(8)$ & 100 & $0.0222(8)$ & $0.2810(7)$ & $0.7272(9)$ & $0.036(2)$ \\
\hline $\mathrm{O}(9)$ & 100 & $0.2675(8)$ & $0.2842(7)$ & $0.7108(9)$ & $0.038(2)$ \\
\hline $\mathrm{O}(10)$ & 100 & $0.3264(8)$ & $0.1187(6)$ & $0.0975(8)$ & $0.0286(18)$ \\
\hline $\mathrm{O}(11)$ & 100 & $0.3691(8)$ & $0.0640(6)$ & $0.2893(8)$ & $0.0298(19)$ \\
\hline $\mathrm{O}(12)$ & 100 & $0.3262(8)$ & $0.9244(6)$ & $0.0992(8)$ & $0.0281(18)$ \\
\hline $\mathrm{O}(13)$ & 100 & $0.5224(8)$ & $0.0963(6)$ & $0.7270(9)$ & $0.037(2)$ \\
\hline $\mathrm{O}(14)$ & 100 & $0.7665(8)$ & $0.0859(7)$ & $0.7082(9)$ & $0.040(2)$ \\
\hline $\mathrm{X}_{\mathrm{M}}^{\mathrm{O}}(1)$ & 100 & $0.9170(7)$ & $0.2051(7)$ & $0.8942(8)$ & $0.032(2)$ \\
\hline $\mathrm{X}_{\mathrm{M}}^{\mathrm{O}}(2)$ & 100 & $0.4184(8)$ & $0.2458(7)$ & $0.8953(8)$ & $0.034(2)$ \\
\hline $\mathrm{X}_{\mathrm{A}}^{\mathrm{O}}(1)$ & 100 & $0.3821(7)$ & $0.9780(6)$ & $0.9072(8)$ & $0.0280(18)$ \\
\hline$X_{A}^{O}(2)$ & 100 & $0.0986(7)$ & $0.0199(6)$ & $0.0888(7)$ & $0.0226(16)$ \\
\hline $\mathrm{X}_{\mathrm{M}}^{P}(1)$ & 100 & $0.8882(12)$ & $0.1537(10)$ & $0.5424(10)$ & $0.056(3)$ \\
\hline $\mathrm{X}_{\mathrm{M}}^{P}(2)$ & 100 & $0.3713(12)$ & $0.1405(10)$ & $0.5431(10)$ & $0.059(3)$ \\
\hline $\mathrm{X}_{\mathrm{A}}^{P}(1)$ & 100 & $0.3767(13)$ & $0.8703(14)$ & $0.5207(15)$ & $0.090(5)$ \\
\hline $\mathrm{X}_{\mathrm{A}}^{P}(2)$ & 24 & $0.125(5)$ & $0.136(3)$ & $0.483(5)$ & $0.034(11)$ \\
\hline W & 76 & $0.1178(16)$ & $0.1003(11)$ & $0.4416(16)$ & $0.041(4)$ \\
\hline \multicolumn{6}{|c|}{ Subsidiary peaks } \\
\hline $\mathrm{M}^{\mathrm{H}}(1 \mathrm{~A})$ & 1 & $0.911(6)$ & $0.264(6)$ & $0.896(7)$ & $0.0196(4)$ \\
\hline $\mathrm{M}^{\mathrm{H}}(1 \mathrm{~B})$ & 6 & $0.9018(15)$ & $0.1325(16)$ & $0.7389(17)$ & $0.0196(4)$ \\
\hline $\mathrm{M}^{\mathrm{H}}(2 \mathrm{~A})$ & 8 & $0.3969(10)$ & $0.1402(9)$ & $0.7403(11)$ & $0.0183(4)$ \\
\hline
\end{tabular}

observed disorder of $\mathrm{Na}$ and $\square$ (vacancy) at the $A^{P}(2)$ site and $\mathrm{H}_{2} \mathrm{O}$ and $\square$ at the $W$ and $\mathrm{X}_{\mathrm{A}}^{P}(2)$ sites, with $\mathrm{A}^{P}(2)-\mathrm{W}=1.65 \AA$ and $\mathrm{X}_{\mathrm{A}}^{P}(2)-\mathrm{W}=0.61 \AA$. Scattering curves for neutral atoms were taken from the International Tables for Crystallography (Wilson, 1992). At the last stages of the refinement, three subsidiary peaks were included in the refinement (scattering curve of $\mathrm{Nb}$ ); these are probably due to the presence of type-II and type-III lamellae intergrown with zvyaginite (Fig. 3). Final atom coordinates and equivalent displacement parameters are given in Table 5, selected interatomic distances and angles in Table 6, refined sitescattering values and assigned site-populations in Table 7, and bond-valence values for selected anions in Table 8. A list of observed and calculated structure factors, a Crystallographic Information File (CIF) and a table of anisotropic displacement parameters have been deposited with the Principal Editor of Mineralogical Magazine and are available from http://www.minersoc.org/pages/e_journals/ dep_mat_mm.html 


\section{E. SOKOLOVA ETAL.}

TABLE 6. Selected interatomic distances $(\AA)$ and angles $\left(^{\circ}\right)$ in zvyaginite.

\begin{tabular}{|c|c|c|c|c|c|}
\hline $\begin{array}{l}\mathrm{M}^{\mathrm{O}}(1)-\mathrm{X}_{\mathrm{A}}^{\mathrm{O}}(1) \mathrm{a} \\
\mathrm{M}^{\mathrm{O}}(1)-\mathrm{O}(10) \\
\mathrm{M}^{\mathrm{O}}(1)-\mathrm{O}(12) \mathrm{b} \\
\mathrm{M}^{\mathrm{O}}(1)-\mathrm{O}(3) \mathrm{a} \\
\mathrm{M}^{\mathrm{O}}(1)-\mathrm{X}_{\mathrm{A}}^{\mathrm{O}}(2) \\
\mathrm{M}^{\mathrm{O}}(1)-\mathrm{O}(7) \mathrm{c} \\
<\mathrm{M}^{\mathrm{O}}(1)-\varphi>\end{array}$ & $\begin{array}{l}1.853(9) \\
1.907(9) \\
1.927(9) \\
2.026(8) \\
2.029(8) \\
2.037(8) \\
1.963\end{array}$ & $\begin{array}{l}\mathrm{M}^{\mathrm{O}}(2)-\mathrm{X}_{\mathrm{M}}^{\mathrm{O}}(2) \mathrm{c} \\
\mathrm{M}^{\mathrm{O}}(2)-\mathrm{O}(10) \\
\mathrm{M}^{\mathrm{O}}(2)-\mathrm{O}(7) \mathrm{c} \\
<\mathrm{M}^{\mathrm{O}}(2)-\mathrm{O}>\end{array}$ & $\begin{array}{ll}2.296(9) & \mathrm{x} 2 \\
2.567(8) & \mathrm{x} 2 \\
2.586(8) & \mathrm{x} 2 \\
2.483 & \end{array}$ & $\begin{array}{l}\mathrm{M}^{\mathrm{O}}(3)-\mathrm{X}_{\mathrm{M}}^{\mathrm{O}}(1) \mathrm{c} \\
\mathrm{M}^{\mathrm{O}}(3)-\mathrm{O}(12) \mathrm{d} \\
\mathrm{M}^{\mathrm{O}}(3)-\mathrm{O}(3) \mathrm{e} \\
<\mathrm{M}^{\mathrm{O}}(3)-\mathrm{O}>\end{array}$ & $\begin{array}{ll}2.295(9) & \mathrm{x} 2 \\
2.557(8) & \mathrm{x} 2 \\
2.587(8) & \mathrm{x} 2 \\
2.479 & \end{array}$ \\
\hline $\begin{array}{l}\mathrm{M}^{\mathrm{O}}(4)-\mathrm{O}(7) \mathrm{c} \\
\mathrm{M}^{\mathrm{O}}(4)-\mathrm{O}(3) \mathrm{f} \\
\mathrm{M}^{\mathrm{O}}(4)-\mathrm{X}_{\mathrm{M}}^{\mathrm{O}}(2) \mathrm{g} \\
\mathrm{M}^{\mathrm{O}}(4)-\mathrm{X}_{\mathrm{M}}^{\mathrm{O}}(1) \mathrm{h} \\
\mathrm{M}^{\mathrm{O}}(4)-\mathrm{X}_{\mathrm{A}}^{\mathrm{O}}(2) \\
\mathrm{M}^{\mathrm{O}}(4)-\mathrm{X}_{\mathrm{A}}^{\mathrm{O}}(2) \mathrm{i} \\
<\mathrm{M}^{\mathrm{O}}(4)-\varphi>\end{array}$ & $\begin{array}{l}2.104(8) \\
2.108(8) \\
2.136(9) \\
2.137(9) \\
2.215(8) \\
2.215(8) \\
2.153\end{array}$ & $\begin{array}{l}\mathrm{M}^{\mathrm{O}}(5)-\mathrm{O}(10) \\
\mathrm{M}^{\mathrm{O}}(5)-\mathrm{O}(12) \mathrm{d} \\
\mathrm{M}^{\mathrm{O}}(5)-\mathrm{X}_{\mathrm{A}}^{\mathrm{O}}(1) \mathrm{e} \\
\mathrm{M}^{\mathrm{O}}(5)-\mathrm{X}_{\mathrm{A}}^{\mathrm{O}}(1) \mathrm{a} \\
\mathrm{M}^{\mathrm{O}}(5)-\mathrm{X}_{\mathrm{M}}^{\mathrm{O}}(2) \mathrm{c} \\
\mathrm{M}^{\mathrm{O}}(5)-\mathrm{X}_{\mathrm{M}}^{\mathrm{O}}(1) \mathrm{j} \\
<\mathrm{M}^{\mathrm{O}}(5)-\varphi>\end{array}$ & $\begin{array}{l}2.32(1) \\
2.34(1) \\
2.43(1) \\
2.45(1) \\
2.46(1) \\
2.49(1) \\
2.42\end{array}$ & $\begin{array}{l}\mathrm{M}^{\mathrm{H}}(1)-\mathrm{X}_{\mathrm{M}}^{\mathrm{O}}(1) \\
\mathrm{M}^{\mathrm{H}}(1)-\mathrm{O}(2) \\
\mathrm{M}^{\mathrm{H}}(1)-\mathrm{O}(8) \mathrm{k} \\
\mathrm{M}^{\mathrm{H}}(1)-\mathrm{O}(6) \mathrm{k} \\
\mathrm{M}^{\mathrm{H}}(1)-\mathrm{O}(14) \\
\mathrm{M}^{\mathrm{H}}(1)-\mathrm{X}_{\mathrm{M}}^{P}(1) \\
<\mathrm{M}^{\mathrm{H}}(1)-\varphi>\end{array}$ & $\begin{array}{l}1.786(9) \\
1.937(9) \\
1.946(9) \\
1.958(8) \\
1.959(8) \\
2.32(1) \\
1.984\end{array}$ \\
\hline $\begin{array}{l}\mathrm{M}^{\mathrm{H}}(2)-\mathrm{X}_{\mathrm{M}}^{\mathrm{O}}(2) \\
\mathrm{M}^{\mathrm{H}}(2)-\mathrm{O}(9) \\
\mathrm{M}^{\mathrm{H}}(2)-\mathrm{O}(5) \\
\mathrm{M}^{\mathrm{H}}(2)-\mathrm{O}(1) \\
\mathrm{M}^{\mathrm{H}}(2)-\mathrm{O}(13) \\
\mathrm{M}^{\mathrm{H}}(2)-\mathrm{X}_{\mathrm{M}}^{\mathrm{P}}(2) \\
<\mathrm{M}^{\mathrm{H}}(2)-\varphi>\end{array}$ & $\begin{array}{l}1.794(9) \\
1.942(9) \\
1.948(9) \\
1.952(8) \\
1.964(8) \\
2.32(1) \\
1.987\end{array}$ & $\begin{array}{l}\mathrm{A}^{P}(1)-\mathrm{X}_{\mathrm{A}}^{P}(1) \\
\mathrm{A}^{P}(1)-\mathrm{X}_{\mathrm{A}}^{\mathrm{O}}(1) \\
\mathrm{A}^{P}(1)-\mathrm{O}(4) \\
\mathrm{A}^{P}(1)-\mathrm{O}(11) \mathrm{e} \\
\mathrm{A}^{P}(1)-\mathrm{O}(13) 1 \\
\mathrm{~A}^{P}(1)-\mathrm{O}(5) 1 \\
\mathrm{~A}^{P}(1)-\mathrm{O}(8) \mathrm{m} \\
\mathrm{A}^{P}(1)-\mathrm{O}(2) \mathrm{n} \\
<\mathrm{A}^{P}(1)-\varphi>\end{array}$ & $\begin{array}{l}2.15(2) \\
2.40(1) \\
2.52(1) \\
2.56(1) \\
2.62(1) \\
2.65(1) \\
2.68(1) \\
2.69(1) \\
2.53\end{array}$ & $\begin{array}{l}\mathrm{A}^{P}(2)-\mathrm{X}_{\mathrm{A}}^{P}(2) \\
\mathrm{A}^{P}(2)-\mathrm{X}_{\mathrm{A}}^{\mathrm{O}}(2) \\
\mathrm{A}^{P}(2)-\mathrm{O}(9) \mathrm{g} \\
\mathrm{A}^{P}(2)-\mathrm{O}(1) \mathrm{g} \\
\mathrm{A}^{P}(2)-\mathrm{O}(6) \mathrm{o} \\
\mathrm{A}^{P}(2)-\mathrm{O}(14) \mathrm{p} \\
\mathrm{A}^{P}(2)-\mathrm{O}(11) \\
\mathrm{A}^{P}(2)-\mathrm{O}(4) \mathrm{f} \\
<\mathrm{A}^{P}(2)-\varphi>\end{array}$ & $\begin{array}{l}2.15(6) \\
2.46(4) \\
2.49(5) \\
2.51(4) \\
2.59(5) \\
2.61(4) \\
2.83(3) \\
2.88(3) \\
2.57\end{array}$ \\
\hline $\begin{array}{l}\mathrm{Si}(1)-\mathrm{O}(1) \mathrm{n} \\
\mathrm{Si}(1)-\mathrm{O}(2) \mathrm{n} \\
\mathrm{Si}(1)-\mathrm{O}(3) \\
\mathrm{Si}(1)-\mathrm{O}(4) \\
<\mathrm{Si}(1)-\mathrm{O}>\end{array}$ & $\begin{array}{l}1.593(8) \\
1.615(9) \\
1.623(9) \\
1.635(8) \\
1.617\end{array}$ & $\begin{array}{l}\mathrm{Si}(2)-\mathrm{O}(6) \\
\mathrm{Si}(2)-\mathrm{O}(5) \\
\mathrm{Si}(2)-\mathrm{O}(7) \\
\mathrm{Si}(2)-\mathrm{O}(4) \mathrm{b} \\
<\mathrm{Si}(2)-\mathrm{O}>\end{array}$ & $\begin{array}{l}1.580(8) \\
1.599(8) \\
1.621(9) \\
1.625(8) \\
1.606\end{array}$ & $\begin{array}{l}\mathrm{Si}(3)-\mathrm{O}(8) \\
\mathrm{Si}(3)-\mathrm{O}(9) \\
\mathrm{Si}(3)-\mathrm{O}(10) \mathrm{g} \\
\mathrm{Si}(3)-\mathrm{O}(11) \mathrm{g} \\
<\mathrm{Si}(3)-\mathrm{O}>\end{array}$ & $\begin{array}{l}1.599(8) \\
1.600(9) \\
1.62(1) \\
1.631(8) \\
1.613\end{array}$ \\
\hline $\begin{array}{l}\mathrm{Si}(4)-\mathrm{O}(13) \mathrm{e} \\
\mathrm{Si}(4)-\mathrm{O}(14) \mathrm{e} \\
\mathrm{Si}(4)-\mathrm{O}(12) \\
\mathrm{Si}(4)-\mathrm{O}(11) 1 \\
<\mathrm{Si}(4)-\mathrm{O}>\end{array}$ & $\begin{array}{l}1.585(8) \\
1.595(9) \\
1.61(1) \\
1.620(9) \\
1.603\end{array}$ & $\begin{array}{l}\mathrm{Si}(1)-\mathrm{O}(4)-\mathrm{Si}(2) 1 \\
\mathrm{Si}(3) \mathrm{g}-\mathrm{O}(11)-\mathrm{Si}(4) \mathrm{b} \\
<\mathrm{Si}-\mathrm{O}-\mathrm{Si}>\end{array}$ & $\begin{array}{l}134.5(6) \\
134.6(6) \\
134.6\end{array}$ & $\begin{array}{l}\text { Short distances } \\
\mathrm{A}^{P}(2)-\mathrm{W} \\
\mathrm{X}_{\mathrm{A}}^{P}(2)-\mathrm{W}\end{array}$ & $\begin{array}{l}1.65(4) \\
0.61(4)\end{array}$ \\
\hline
\end{tabular}

$\varphi=\mathrm{O}, \mathrm{F}, \mathrm{OH}, \mathrm{H}_{2} \mathrm{O}$; Symmetry operators: a: $\mathrm{x}, \mathrm{y}-1, \mathrm{z}-1 ; \mathrm{b}: \mathrm{x}, \mathrm{y}-1, \mathrm{z} ; \mathrm{c}: \mathrm{x}, \mathrm{y}, \mathrm{z}-1 ; \mathrm{d}:-\mathrm{x}+1,-\mathrm{y}+1,-\mathrm{z} ; \mathrm{e}:-\mathrm{x}+1,-\mathrm{y}+1,-$ $\mathrm{z}+1 ; \mathrm{f}:-\mathrm{x},-\mathrm{y}+1,-\mathrm{z}+1 ; \mathrm{g}:-\mathrm{x}+1 / 2,-\mathrm{y}+1 / 2,-\mathrm{z}+1 ; \mathrm{h}: \mathrm{x}-1, \mathrm{y}, \mathrm{z}-1 ; \mathrm{i}:-\mathrm{x},-\mathrm{y},-\mathrm{z} ; \mathrm{j}: \mathrm{x}+3 / 2,-\mathrm{y}+1 / 2,-\mathrm{z}+1 ; \mathrm{k}: \mathrm{x}+1, \mathrm{y}, \mathrm{z} ; 1$ : $\mathrm{x}, \mathrm{y}+1, \mathrm{z} ; \mathrm{m}: \mathrm{x}+1 / 2, \mathrm{y}+1 / 2, \mathrm{z} ; \mathrm{n}: \mathrm{x}-1 / 2, \mathrm{y}+1 / 2, \mathrm{z} ; \mathrm{o}:-\mathrm{x},-\mathrm{y},-\mathrm{z}+1 ; \mathrm{p}:-\mathrm{x}+1,-\mathrm{y},-\mathrm{z}+1$.

\section{Site-population assignment}

There are thirteen cation sites in the crystal structure of zvyaginite: the $M^{\mathrm{H}}(1,2), A^{P}(1,2)$ and four $S i$ sites of the $\mathrm{H}$ sheet and five $M^{\mathrm{O}}$ sites of the $\mathrm{O}$ sheet; site labelling follows Sokolova (2006).

The two ${ }^{[6]} M^{\mathrm{H}}$ sites in the $\mathrm{H}$ sheet have refined site-scattering values of 36.5(3) and 36.0(3) electrons per formula unit (epfu) (Table 7) and we assign all $\mathrm{Nb}$ plus some Ti to those two sites. In the $\mathrm{O}$ sheet, the refined site-scattering at the $M^{\mathrm{O}}(1)$ site is 21.4(5) epfu (Table 7) and the bond-lengths around this site vary from 1.853 to $2.037 \AA$
(Table 6); we assign the rest of Ti plus minor $\mathrm{Al}$ to the $M^{\mathrm{O}}(1)$ site, with a calculated scattering of 21.37 epfu (Table 7).

The two ${ }^{[6]} M^{\mathrm{O}}(2,3)$ sites occur in the $\mathrm{O}$ sheet. The refined site-scattering at the $M^{\mathrm{O}}(2)$ site, 2.6(2) epfu, is slightly lower than 2.8(2) epfu at the $M^{\mathrm{O}}(3)$ site (Table 7), and the mean bond-length for the $M^{\mathrm{O}}(2)$ site, $2.483 \AA$, is slightly longer than $2.479 \AA$ at the $M^{\mathrm{O}}(3)$ site (Table 6) and we assign $(0.24 \mathrm{Na}+0.26 \square)$ apfu to the $M^{\mathrm{O}}(2)$ site and $(0.18$ $\mathrm{Na}+0.03 \mathrm{Mn}+0.29 \square)$ apfu to the $M^{\mathrm{O}}(3)$ site, with calculated site-scattering values of 2.64 and 2.73 epfu, respectively (Table 7). 
TABLE 7. Refined site-scattering and assigned site-populations for zvyaginite, space group $C \overline{1}$.

\begin{tabular}{|c|c|c|c|c|c|c|}
\hline Site* & & $\begin{array}{l}\text { Refined site- } \\
\text { scattering } \\
\text { (epfu) }\end{array}$ & $\begin{array}{l}\text { Assigned site- } \\
\text { population (pfu) }\end{array}$ & $\begin{array}{l}\text { Calculated site- } \\
\text { scattering (epfu) }\end{array}$ & $\begin{array}{l}<\text { cation }- \\
\varphi>_{\text {obs. }}(\AA)\end{array}$ & $\begin{array}{l}\text { Ideal } \\
\text { composition } \\
\text { (pfu) }\end{array}$ \\
\hline \multicolumn{7}{|l|}{ Cations } \\
\hline$M^{\mathrm{H}}(1)$ & {$[N b(1)]$} & $36.5(3)$ & $0.84 \mathrm{Nb}+0.16 \mathrm{Ti}$ & 37.96 & 1.984 & $\mathrm{Nb}$ \\
\hline$M^{\mathrm{H}}(2)$ & {$[N b(2)]$} & $36.0(3)$ & $0.84 \mathrm{Nb}+0.16 \mathrm{Ti}$ & 37.96 & 1.987 & $\mathrm{Nb}$ \\
\hline$M^{\mathrm{O}}(1)$ & {$[\operatorname{Ti}(1,2)]$} & $21.4(5)$ & $0.93 \mathrm{Ti}+0.07 \mathrm{Al}$ & 21.37 & 1.963 & $\mathrm{Ti}$ \\
\hline$\Sigma$ & & 93.9 & $\begin{array}{l}1.68 \mathrm{Nb}+1.25 \mathrm{Ti}+ \\
0.07 \mathrm{Al}\end{array}$ & 97.29 & & $\mathrm{Nb}_{2} \mathrm{Ti}$ \\
\hline$M^{\mathrm{O}}(2)$ & {$[\mathrm{Na}(1)]$} & $2.6(2)$ & $0.24 \mathrm{Na}+0.26 \square$ & 2.64 & 2.483 & $\square_{0.5}$ \\
\hline$M^{\mathrm{O}}(3)$ & & $2.8(2)$ & $\begin{array}{l}0.18 \mathrm{Na}+0.03 \mathrm{Mn}+ \\
0.29 \square\end{array}$ & 2.73 & 2.479 & $\square_{0.5}$ \\
\hline$M^{\mathrm{O}}(4)$ & {$[Z n(1)]$} & $24.5(2)$ & $\begin{array}{c}0.61 \mathrm{Zn}+0.22 \mathrm{Na}+ \\
0.10 \mathrm{Mn}+0.04 \\
\mathrm{Fe}^{2+}+0.03 \square\end{array}$ & 24.26 & 2.153 & $\mathrm{Zn}$ \\
\hline$M^{\mathrm{O}}(5)$ & {$[Z n(2)]$} & $14.2(3)$ & $\begin{array}{r}0.48 \mathrm{Na}+0.27 \mathrm{Zn}+ \\
0.04 \mathrm{Mn}+0.21 \square\end{array}$ & 14.38 & 2.42 & $\mathrm{Na}$ \\
\hline$\Sigma$ & & 44.1 & $\begin{array}{c}1.12 \mathrm{Na}+0.88 \mathrm{Zn}+ \\
0.17 \mathrm{Mn}+0.04 \\
\mathrm{Fe}^{2+}+0.79 \square\end{array}$ & 44.01 & & $\mathrm{NaZn} \square$ \\
\hline${ }^{[8]} A^{P}(1)$ & {$[N a(2)]$} & $7.9(2)$ & $\begin{array}{l}0.55 \mathrm{Na}+0.09 \mathrm{Ca}+ \\
0.36 \square\end{array}$ & 7.85 & 2.53 & $\mathrm{Na}$ \\
\hline${ }^{[8]} A^{P}(2)$ & {$[\mathrm{Na}(3)]$} & $3.0(3)$ & $\begin{array}{l}0.20 \mathrm{Na}+0.04 \mathrm{~K}+ \\
\quad 0.76 \square\end{array}$ & 2.96 & 2.57 & $\square$ \\
\hline$\Sigma$ & & 10.9 & $\begin{array}{c}0.75 \mathrm{Na}+0.09 \mathrm{Ca}+ \\
0.04 \mathrm{~K}+1.12 \square\end{array}$ & 10.81 & & $\mathrm{Na} \square$ \\
\hline \multicolumn{7}{|c|}{ Anions** and $\mathrm{H}_{2} \mathrm{O}$ groups } \\
\hline $\mathrm{X}_{\mathrm{M}}^{\mathrm{O}}(1,2)$ & {$[\mathrm{O}(6,18)]$} & & $2.00 \mathrm{O}$ & & & $\mathrm{O}_{2}$ \\
\hline${ }^{[4,3]} \mathrm{X}_{\mathrm{A}}^{\mathrm{O}}(1,2)$ & {$[\mathrm{O}(11,12)]$} & & $1.11 \mathrm{OH}+0.89 \mathrm{~F}$ & & & $(\mathrm{OH})_{2}$ \\
\hline${ }^{[1]} \mathrm{X}_{\mathrm{M}}^{P}(1,2)$ & {$[\mathrm{O}(19,20)]$} & & $2.00 \mathrm{H}_{2} \mathrm{O}$ & & & $\left(\mathrm{H}_{2} \mathrm{O}\right)_{2}$ \\
\hline${ }^{[1]} \mathrm{X}_{\mathrm{A}}^{P}(1)$ & {$[\mathrm{O}(21)]$} & & $1.00 \mathrm{H}_{2} \mathrm{O}$ & & & $\mathrm{H}_{2} \mathrm{O}$ \\
\hline${ }^{[1]} \mathrm{X}_{\mathrm{A}}^{P}(2)$ & {$[\mathrm{O}(22)]$} & & $0.24 \mathrm{H}_{2} \mathrm{O}+0.76 \square$ & & & $\square$ \\
\hline$W$ & & & $0.76 \mathrm{H}_{2} \mathrm{O}+0.24 \square$ & & & $\mathrm{H}_{2} \mathrm{O}$ \\
\hline$\Sigma$ & & & $\begin{array}{r}2.00 \mathrm{O}+1.11 \mathrm{OH}+ \\
0.89 \mathrm{~F}+4.00 \mathrm{H}_{2} \mathrm{O}\end{array}$ & & & $\begin{array}{r}\mathrm{O}_{2}(\mathrm{OH})_{2} \\
\left(\mathrm{H}_{2} \mathrm{O}\right)_{4}\end{array}$ \\
\hline
\end{tabular}

*Coordination numbers are shown for non-[6]-coordinated cation sites and non-4-coordinated anion sites and $\mathrm{H}_{2} \mathrm{O}$ groups; [ ] corresponding sites in Pekov et al. (2014); $\varphi=\mathrm{O}, \mathrm{F}, \mathrm{OH}, \mathrm{H}_{2} \mathrm{O}$; the Ti-dominant general $M^{\mathrm{O}}(1)$ site (this work) corresponds to the two, Ti(1) and Ti(2), special sites (multiplicity 0.5 apfu) (Pekov et al., 2014); the special $M^{\mathrm{O}}(2)$ and $M^{\mathrm{O}}(3)$ sites (multiplicity $0.5 \mathrm{apfu}$ ) occupied mainly by $\mathrm{Na}$ at $<50 \%$ (this work) correspond to the general $\mathrm{Na}(1)$ site (Pekov et al., 2014) with 46\% occupancy.

**Anions that do not coordinate Si.

The two [8]-coordinated $A^{P}(1)$ and $A^{P}(2)$ sites in the $\mathrm{H}$ sheet have refined site-scattering values of $7.9(2)$ and 3.0(3) epfu and mean bond lengths of 2.53 and $2.57 \AA$ (Table 7). We assign $(0.55 \mathrm{Na}+0.09 \mathrm{Ca}+0.36$ $\square)$ pfu to the $A^{P}(1)$ site and $(0.20 \mathrm{Na}+0.04 \mathrm{~K}+0.76$ $\square)$ pfu to the $A^{P}(2)$ site, with calculated site-scattering values of 7.85 and 2.96 epfu, respectively (Table 7).
We are left with $0.88 \mathrm{Zn}+0.70 \mathrm{Na}+0.14 \mathrm{Mn}+$ $0.04 \mathrm{Fe}^{2+}$ (Table 2) to assign to the [6]-coordinated $M^{\mathrm{O}}(4)$ and $M^{\mathrm{O}}(5)$ sites in the $\mathrm{O}$ sheet. The refined site-scattering of 24.5 epfu at the $M^{\mathrm{O}}(4)$ site is higher than that at the $M^{\mathrm{O}}(5)$ site: $14.2 \mathrm{epfu}$, and the $<\mathrm{M}^{\mathrm{O}}(4)-\varphi>$ distance of $2.153 \AA$ [with a calculated aggregate cation $r=0.77 \AA, c f .{ }^{[6]} \mathrm{Zn}: r=0.74 \AA$, 


\section{E. SOKOLOVA ETAL.}

TABLE 8. Bond-valence values for selected anions* in zvyaginite.

\begin{tabular}{lllllllllll}
\hline Atom & $\mathrm{M}^{\mathrm{O}}(1)$ & $\mathrm{M}^{\mathrm{O}}(2)$ & $\mathrm{M}^{\mathrm{O}}(3)$ & $\mathrm{M}^{\mathrm{O}}(4)$ & $\mathrm{M}^{\mathrm{O}}(5)$ & $\mathrm{M}^{\mathrm{H}}(1)$ & $\mathrm{M}^{\mathrm{H}}(2)$ & $\mathrm{A}^{P}(1)$ & $\mathrm{A}^{P}(2)$ & $\Sigma$ \\
Site occ. (\%) & 100 & 48 & 42 & 97 & 79 & 100 & 100 & 74 & 24 & \\
\hline $\mathrm{X}_{\mathrm{M}}^{\mathrm{O}}(1)$ & & & 0.10 & 0.30 & 0.12 & 1.39 & & & & 1.91 \\
$\mathrm{X}_{\mathrm{M}}^{\mathrm{O}}(2)$ & & 0.10 & & 0.30 & 0.12 & & 1.36 & & \\
$\mathrm{X}_{\mathrm{A}}^{\mathrm{O}}(1)$ & 0.87 & & & & 0.13 & & & 0.14 & & 1.88 \\
& & & & & 0.13 & & & & & \\
$\mathrm{X}_{\mathrm{A}}^{\mathrm{O}}(2)$ & 0.55 & & & 0.24 & & & & & 0.04 & 1.07 \\
$\mathrm{X}_{\mathrm{M}}^{P}(1)$ & & & & 0.24 & & & & & & 0.38 \\
$\mathrm{X}_{\mathrm{M}}^{P}(2)$ & & & & & & 0.38 & & & & \\
$\mathrm{X}_{\mathrm{A}}^{P}(1)$ & & & & & & & 0.38 & & & 0.38 \\
$\mathrm{X}_{\mathrm{A}}^{P}(2)$ & & & & & & & & 0.33 & & 0.33 \\
& & & & & & & & & 0.33 & 0.33
\end{tabular}

* Anions which do not coordinate Si; bond-valence parameters (vu) are from Brown (1981); bonds to oxygen were used for Ti $\left[\mathrm{M}^{\mathrm{O}}(1)\right] ; \mathrm{Na}\left[\mathrm{M}^{\mathrm{O}}(2,3,5), \mathrm{A}^{P}(1,2)\right] ; \mathrm{Zn}\left[\mathrm{M}^{\mathrm{O}}(4)\right]$ and $\mathrm{Nb}\left[\mathrm{M}^{\mathrm{H}}(1,2)\right]$; site occupancies of cation sites were taken into account for all calculations except for $A^{P}(2)$ and $\mathrm{X}_{\mathrm{A}}^{P}$. (2): both sites are occupied at $24 \%$ by $\mathrm{Na}$ and $\mathrm{H}_{2} \mathrm{O}$, respectively.

Shannon (1976)] is shorter than the $\left\langle\mathrm{M}^{\mathrm{O}}(5)-\varphi>\right.$ distance of $2.42 \AA$ [with a calculated aggregate cation $r=1.14 \AA$, cf. $\left.{ }^{[6]} \mathrm{Na}: r=1.02 \AA\right]$. Therefore we assign $(0.61 \mathrm{Zn}+0.22 \mathrm{Na}+0.10 \mathrm{Mn}+0.04$ $\left.\mathrm{Fe}^{2+}+0.03 \square\right)$ pfu to the $M^{\mathrm{O}}(4)$ site, with a calculated site-scattering of 24.26 epfu and $(0.48$ $\mathrm{Na}+0.27 \mathrm{Zn}+0.04 \mathrm{Mn}+0.21 \square)$ apfu to the $M^{\mathrm{O}}(5)$ site, with a calculated site-scattering of 14.38 epfu (Table 7).

\section{Description of the structure}

\section{Cation and anion sites}

Here we consider thirteen cation sites, five $M^{\mathrm{O}}$ sites of the $\mathrm{O}$ sheet and two $M^{\mathrm{H}}$, two $A^{P}$ and four $S i$ sites of the $\mathrm{H}$ sheet; and eight anion sites: two $\mathrm{X}_{\mathrm{M}}^{\mathrm{O}}=$ anion sites at the common vertices of $3 \mathrm{M}^{\mathrm{O}}$ and $\mathrm{M}^{\mathrm{H}}$ polyhedra; two $\mathrm{X}_{\mathrm{A}}^{\mathrm{O}}=$ anion sites at the common vertices of $3 \mathrm{M}^{\mathrm{O}}$ and $\mathrm{A}^{P}$ polyhedra; four $\mathrm{X}_{(\mathrm{M}, \mathrm{A})}^{P}=$ anion sites at the apical vertices of two $\mathrm{M}^{\mathrm{H}}$ and two $\mathrm{A}^{P}$ polyhedra at the periphery of the TS block; labelling is in accord with Sokolova (2006).

In the $\mathrm{O}$ sheet, the $M^{\mathrm{O}}(1)$ site is occupied primarily by $\mathrm{Ti}$ with minor $\mathrm{Al}$ (Table 7), and it is coordinated by four $\mathrm{O}$ atoms and two $(\mathrm{OH}, \mathrm{F})$ anions at the $\mathrm{X}_{\mathrm{A}}^{\mathrm{O}}$ sites as in epistolite (Figs $4 a, b$ ). The ideal composition of the $M^{\mathrm{O}}(1)$ site is Ti apfu. Note that Pekov et al. (2014) reported two $\operatorname{Ti}(1,2)$ sites, each occupied by $0.5 \mathrm{Ti}$ apfu (Table 3 ). The $\square$-dominant ${ }^{[6]} M^{\mathrm{O}}(2)$ and ${ }^{[6]} M^{\mathrm{O}}(3)$ sites are less than $50 \%$ occupied by $\mathrm{Na}$ and $\mathrm{Na}$ with minor $\mathrm{Mn}$, respectively (Table 7, Fig. $4 a$ ). The $M^{\mathrm{O}}(2,3)$ sites are coordinated by six $\mathrm{O}$ atoms, with $<\mathrm{M}^{\mathrm{O}}(2,3)-$ $\mathrm{O}>=2.483$ and $2.479 \AA$ (Table 6). The ideal composition of the $M^{\mathrm{O}}(2,3)$ sites is $\square_{0.5}+\square_{0.5}=$ $\square$ pfu (Table 7). Note that Pekov et al. (2014) reported one $N a(1)$ site, ideally $\square$ pfu (Table 3). The $M^{\mathrm{O}}(4)$ site is occupied primarily by $\mathrm{Zn}$ plus $\mathrm{Na}$ and $\mathrm{Mn}$ with minor $\mathrm{Fe}^{2+}$ (Table 7, Fig. $4 a$ ), and is coordinated by four $\mathrm{O}$ atoms and two $(\mathrm{OH}, \mathrm{F})$ anions at the $\mathrm{X}_{\mathrm{A}}^{\mathrm{O}}$ sites, with $\left\langle\mathrm{M}^{\mathrm{O}}(4)-\varphi>=2.153 \AA\right.$ (Table 6). The ideal composition of the $M^{\mathrm{O}}(4)$ site is $\mathrm{Zn}$ apfu. The $M^{\mathrm{O}}(5)$ site is occupied $79 \%$ by $\mathrm{Na}$ plus $\mathrm{Zn}$ and minor Mn (Table 7, Fig. 4a), and it is coordinated by four $\mathrm{O}$ atoms and two $(\mathrm{OH}, \mathrm{F})$ anions at the $\mathrm{X}_{\mathrm{A}}^{\mathrm{O}}$ sites, with $\left\langle\mathrm{M}^{\mathrm{O}}(5)-\varphi>=2.42 \AA\right.$ (Table 6). The ideal composition of the $M^{\mathrm{O}}(5)$ site is Na apfu. Note that Pekov et al. (2014) reported two $Z n(1,2)$ sites with $\sim 60 \%$ occupancy by $Z n$ (Table 3), which ideally give $Z n_{2}$ apfu. These $Z n(1,2)$ sites correspond to the $M^{\mathrm{O}}(4,5)$ sites (Table 7). The $U_{\text {eq }}$ of $\mathrm{Zn}$ atoms at the $Z n(1,2)$ sites were in the ratio 1:3 (Pekov et al., 2014), inconsistent with equal occupancy of those sites. The $U_{\text {eq }}$ of $\mathrm{Zn}$ and $\mathrm{Na}$ atoms at the $M^{\mathrm{O}}(4)$ and $M^{\mathrm{O}}(5)$ sites are in the ratio 2:3 (this work) and we suggest that the larger cation disorder (and a larger vacancy) at the $M^{\mathrm{O}}(5)$ site results in larger values of displacement parameters.

The sum of the cations at the $M^{\mathrm{O}}(4,5,2,3,1)$ sites gives ideal composition of the $\mathrm{O}$ sheet as $\mathrm{NaZn} \square$ Ti pfu.

In the $\mathrm{H}$ sheet, there are four tetrahedrally coordinated $\mathrm{Si}(1-4)$ sites occupied by $\mathrm{Si}$. There are two Nb-dominant ${ }^{[6]} M^{\mathrm{H}}(1,2)$ sites; each $M^{\mathrm{H}}$ site is coordinated by five $\mathrm{O}$ atoms and an $\mathrm{H}_{2} \mathrm{O}$ group at 

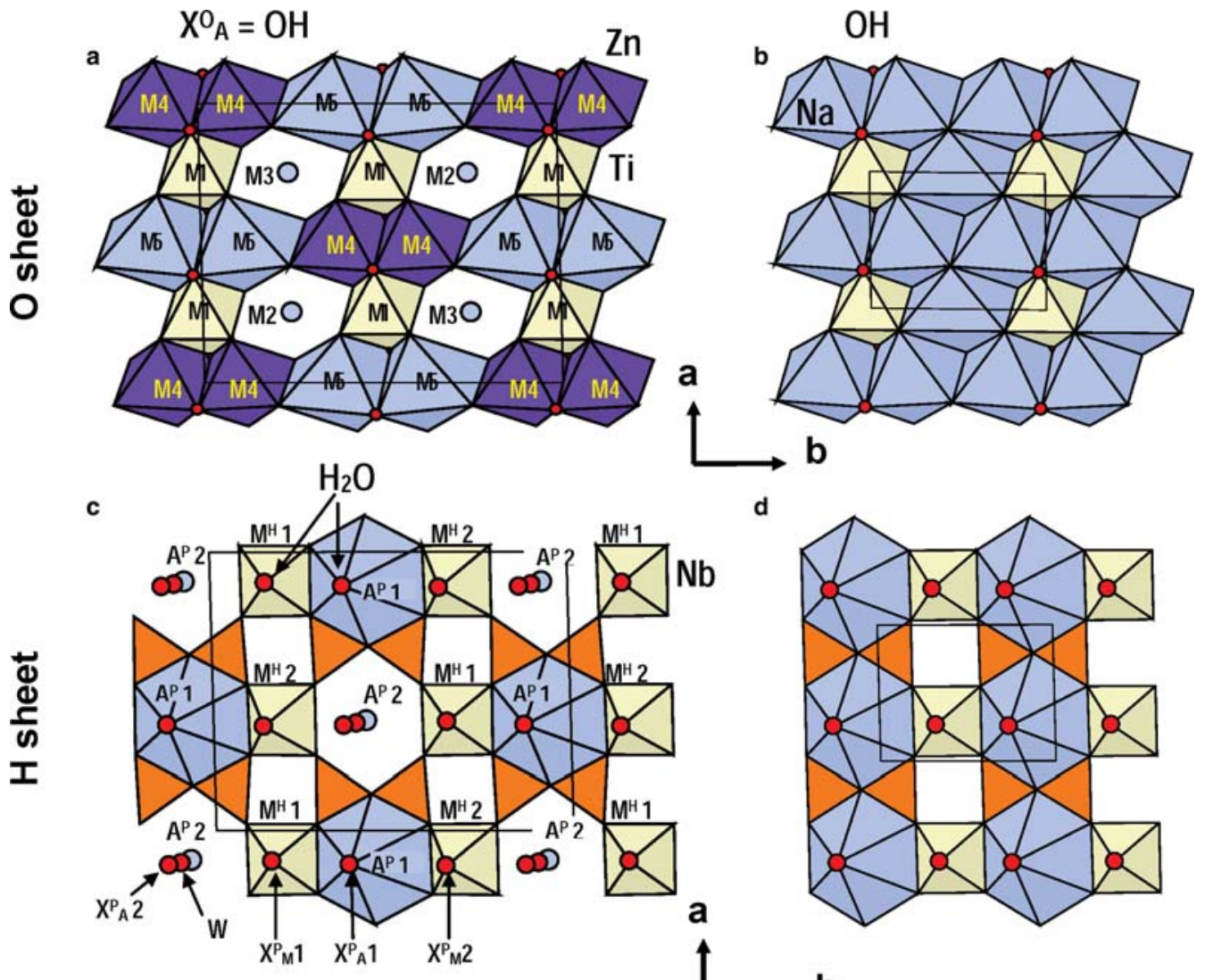

d
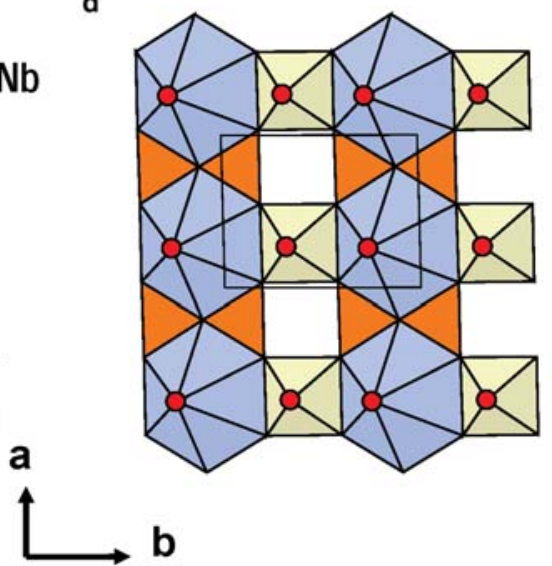

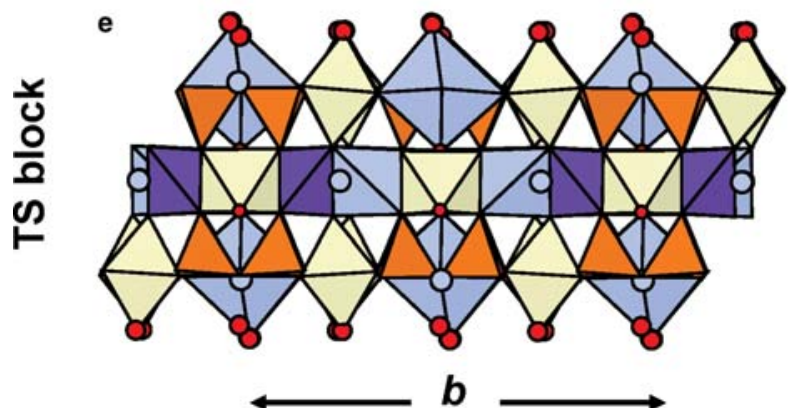

Zvyaginite

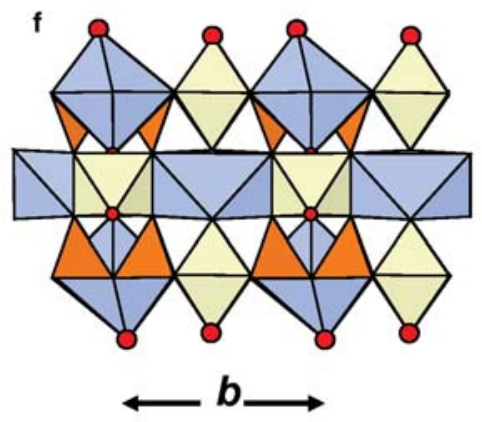

Epistolite

FIg. 4. The details of the TS block: the $\mathrm{O}$ sheet of Na-dominant $\mathrm{M}^{\mathrm{O}}(5)$ octahedra, Ti-dominant $\mathrm{M}^{\mathrm{O}}(1)$ octahedra and $\mathrm{Zn}$ dominant $\mathrm{M}^{\mathrm{O}}(4)$ octahedra $\left[M^{\mathrm{O}}(2,3)\right.$ sites are occupied by $\mathrm{Na}$ at less than $\left.50 \%\right]$ in zvyaginite $(a)$ and the $\mathrm{O}$ sheet of $\mathrm{Na}$ and $\mathrm{Ti}$ octahedra in epistolite $(b)$; the $\mathrm{H}$ sheet of $\mathrm{Si}_{2} \mathrm{O}_{7}$ groups, Nb-dominant $\mathrm{M}^{\mathrm{H}}$ octahedra and [8]-coordinated Na-dominant $A^{P}(1)$ polyhedra (64\% occupancy) [the $A^{P}(2)$ site is occupied by $\mathrm{Na}$ at $24 \%$ ] in zvyaginite $(c)$ and the $\mathrm{H}$ sheet of $\mathrm{Si}_{2} \mathrm{O}_{7}$ groups, $\mathrm{Nb}$-dominant octahedra and [8]-coordinated Na-dominant polyhedra (59\% occupancy) in epistolite $(d)$; the TS block in zvyaginite $(e)$ and epistolite $(f)$. Si tetrahedra are orange, Nb-dominant and Ti-dominant octahedra are yellow; Na-dominant and $\mathrm{Zn}$-dominant polyhedra are navy blue and purple, $\mathrm{OH}$ groups at the $X_{\mathrm{A}}^{\mathrm{O}}$ sites are shown as medium red spheres, $\mathrm{H}_{2} \mathrm{O}$ groups at the $X^{P}$ and $W$ sites are shown as large red spheres, cation sites with $<50 \%$ occupancy by $\mathrm{Na}$ are shown as navy blue spheres. The unit cell is shown by thin black lines in $(a-d)$. 


\section{E. SOKOLOVA ETAL.}

the $X_{\mathrm{M}}^{P}$ site as in epistolite (Figs $4 c, d$ ). The $M^{\mathrm{H}}(1,2)$ sites ideally give $\mathrm{Nb}_{2}$ apfu. Note that the $U_{\text {eq }}$ of $\mathrm{Nb}$ atoms at the $M^{\mathrm{H}}(1,2)$ sites are in the ratio $1: 1$. The two ${ }^{[8]} A^{P}(1,2)$ sites are occupied $64 \%$ by $\mathrm{Na}$ and minor $\mathrm{Ca}$ and $24 \%$ by $\mathrm{Na}$ and minor $\mathrm{K}$, respectively; ideally they give $\mathrm{Na} \square$ pfu (Table 7). Each $A^{P}$ site is coordinated by six $\mathrm{O}$ atoms, an $\mathrm{OH}$ group at the $X_{\mathrm{A}}^{\mathrm{O}}$ site and an $\mathrm{H}_{2} \mathrm{O}$ group at the $X_{\mathrm{A}}^{P}$ site, as in epistolite (Table 6, Figs $4 c, d$ ). The ideal composition of the $A^{P}+M^{\mathrm{H}}$ sites is $\mathrm{Na} \square \mathrm{Nb}_{2}$ pfu.

We write the cation part of the TS block as the sum of cations of the $2 \mathrm{H}$ and $\mathrm{O}$ sheets: ideally $\mathrm{Na} \square \mathrm{Nb}_{2} \mathrm{NaZn} \square \mathrm{Ti}$ pfu, with a total charge of $18^{+}$.

The four $\mathrm{Si}(1-4)$ atoms and fourteen $\mathrm{O}(1-14)$ atoms (Table 5) that coordinate the $\mathrm{Si}$ atoms give $\left(\mathrm{Si}_{2} \mathrm{O}_{7}\right)_{2}$ pfu. Anions at the $X_{\mathrm{M}}^{\mathrm{O}}(1$ and 2) sites receive bond valences from four cations: $\mathrm{M}^{\mathrm{O}}(3$ and 2), $\mathrm{M}^{\mathrm{O}}(4), \mathrm{M}^{\mathrm{O}}(5)$ and $\mathrm{M}^{\mathrm{H}}$, with total bond-valence sums of 1.91 and $1.88 \mathrm{vu}$ (valence units) (Table 8) and they are $\mathrm{O}$ atoms, giving $\mathrm{O}_{2}$ apfu (Table 7). Anions at the $X_{\mathrm{A}}^{\mathrm{O}}(1$ and 2) sites receive bond valences from four cations: $\mathrm{M}^{\mathrm{O}}(1), 2 \mathrm{M}^{\mathrm{O}}(5$ and 4$)$ and $\mathrm{A}^{P}(1$ and 2$)$, with total bond-valence sums of 1.27 and $1.07 \mathrm{vu}$ (Table 8, Fig. $4 a$ ) and we assign monovalent anions to these two sites: $1.11 \mathrm{OH}+$ $0.89 \mathrm{~F}$, ideally $(\mathrm{OH})_{2}$ pfu (Table 7). The four $X_{(\mathrm{M}, \mathrm{A})}^{P}$ sites are occupied by $\mathrm{H}_{2} \mathrm{O}$ groups (Tables 8, Fig. $4 c$ ) as in epistolite (Fig. 4d) (Sokolova and Hawthorne, 2004). The $X_{\mathrm{M}}^{P}(1,2)$ and $X_{\mathrm{A}}^{P}(1)$ sites are occupied by $\mathrm{H}_{2} \mathrm{O}$ at $100 \%$ and the $X_{\mathrm{A}}^{P}(2)$ site at $24 \%$ (Tables 7). There is a new $W$ site (when compared to epistolite) which is occupied by $\mathrm{H}_{2} \mathrm{O}$ groups at $76 \%$ (Tables 5,7). The four $X_{(\mathrm{M}, \mathrm{A})}^{P}$ sites and the $W$ site give $\left(\mathrm{H}_{2} \mathrm{O}\right)_{4}$ pfu (Table 7). The anions and $\mathrm{H}_{2} \mathrm{O}$ groups sum as follows: $\left(\mathrm{Si}_{2} \mathrm{O}_{7}\right)_{2}[\mathrm{O}(1-14)]+\mathrm{O}_{2}+$ $(\mathrm{OH})_{2}+\left(\mathrm{H}_{2} \mathrm{O}\right)_{4}=\left(\mathrm{Si}_{2} \mathrm{O}_{7}\right)_{2} \mathrm{O}_{2}(\mathrm{OH})_{2}\left(\mathrm{H}_{2} \mathrm{O}\right)_{4}$ pfu, with a total charge of $18^{-}$. We write ideal structural formula of zvyaginite as the sum of cation and anion parts: $\mathrm{Na} \square \mathrm{Nb}_{2} \mathrm{NaZn} \square \mathrm{Ti}+\left(\mathrm{Si}_{2} \mathrm{O}_{7}\right)_{2} \mathrm{O}_{2}(\mathrm{OH})_{2}$ $\left(\mathrm{H}_{2} \mathrm{O}\right)_{4}=\mathrm{Na} \square \mathrm{Nb}_{2} \mathrm{NaZn} \square \mathrm{Ti}\left(\mathrm{Si}_{2} \mathrm{O}_{7}\right)_{2} \mathrm{O}_{2}(\mathrm{OH})_{2}$ $\left(\mathrm{H}_{2} \mathrm{O}\right)_{4}, \mathrm{Z}=4$. A short form of the ideal structural formula is $\mathrm{Na}_{2} \mathrm{ZnTiNb}_{2}\left(\mathrm{Si}_{2} \mathrm{O}_{7}\right)_{2} \mathrm{O}_{2}(\mathrm{OH})_{2}\left(\mathrm{H}_{2} \mathrm{O}\right)_{4}$.

\section{Structure topology of zvyaginite}

The main structural unit in the crystal structure of zvyaginite is a TS block that consists of $\mathrm{HOH}$ sheets. The $\mathrm{O}$ sheet is composed of Ti-dominant $\mathrm{M}^{\mathrm{O}}(1)$, Zn-dominant $\mathrm{M}^{\mathrm{O}}(4)$ and Na-dominant $\mathrm{M}^{\mathrm{O}}(5)$ octahedra, with $\square$-dominant $M^{\mathrm{O}}(2,3)$ sites occupied mainly by $\mathrm{Na}$ at $<50 \%$ (Fig. $4 a$ ). In epistolite, Ti-dominant and $\mathrm{Na}$-dominant octahedra constitute the $\mathrm{O}$ sheet (Fig. 4b). The ideal compositions of the $\mathrm{O}$ sheet in zvyaginite, $\left[\mathrm{Na} \square \mathrm{ZnTiO}_{2}(\mathrm{OH})_{2}\right]^{1+}$ pfu, and epistolite, $\left[\mathrm{Na}_{3} \mathrm{TiO}_{2}(\mathrm{OH})_{2}\right]^{1+}$ apfu (Sokolova and Hawthorne, 2004) are related by the following substitution: $\left(\mathrm{Na}_{2}^{+}\right)_{\mathrm{epi}} \leftrightarrow \mathrm{Zn}_{\mathrm{zvy}}^{2+}+\square_{\mathrm{zvy}}$.

In zvyaginite, the $\mathrm{H}$ sheet is built of $\mathrm{Si}_{2} \mathrm{O}_{7}$ groups, Nb-dominant ${ }^{[6]} \mathrm{M}^{\mathrm{H}}$ and Na-dominant ${ }^{[8]} \mathrm{A}^{P}(1)$ polyhedra, with the $\square$-dominant ${ }^{[8]} A^{P}(2)$ site occupied mainly by $\mathrm{Na}$ at $24 \%$ (Fig. $4 c$ ). In epistolite, there is only one ${ }^{[8]} A^{P}$ site occupied mainly by $\mathrm{Na}$ at 59\% (Fig. 4d) and Sokolova and Hawthorne (2004) wrote its composition as $(\mathrm{Na} \square)$ pfu, with cations of the two $\mathrm{H}$ sheets summing to $(\mathrm{Na} \square) \mathrm{Nb}_{2}$ pfu. Hence ideal compositions of the $\mathrm{H}$ sheets in zvyaginite, $\left[\mathrm{Na} \square \mathrm{Nb}_{2}\left(\mathrm{Si}_{2} \mathrm{O}_{7}\right)_{2}\left(\mathrm{H}_{2} \mathrm{O}\right)_{4}\right]^{1-}$ pfu, and epistolite, $\left[(\mathrm{Na} \square) \mathrm{Nb}_{2}\left(\mathrm{Si}_{2} \mathrm{O}_{7}\right)_{2}\left(\mathrm{H}_{2} \mathrm{O}\right)_{4}\right]^{1-}$ pfu are quantitatively identical but differ in the order of $\mathrm{Na}$ and $\square$ over two $A^{P}$ sites in zvyaginite and the disorder of $\mathrm{Na}$ and $\square$ within one $A^{P}$ site in epistolite.

In zvyaginite and epistolite, the topology of the TS block is as in the lamprophyllite group of the TS-block minerals where $\mathrm{Ti}\left(+\mathrm{Nb}+\mathrm{Fe}^{3+}+\mathrm{Mg}\right)=$ 3 apfu per $\left(\mathrm{Si}_{2} \mathrm{O}_{7}\right)_{2}$ : two $\mathrm{H}$ sheets connect to the $\mathrm{O}$ sheet such that two $\mathrm{Si}_{2} \mathrm{O}_{7}$ groups link to the trans edges of a $\mathrm{Ti}\left[\mathrm{M}^{\mathrm{O}}(1)\right]$ octahedron of the $\mathrm{O}$ sheet (Figs $4 e, f$ ). In the crystal structures of zvyaginite and epistolite, TS blocks parallel to (001) link via hydrogen bonds between $\mathrm{H}_{2} \mathrm{O}$ groups at apical vertices $\left[X_{(\mathrm{M}, \mathrm{A})}^{P}\right.$ sites $]$ of $\mathrm{M}^{\mathrm{H}}$ and $\mathrm{A}^{P}$ polyhedra (Fig. 5a,b).

Figure 6 shows $\mathrm{H}_{2} \mathrm{O}$ groups forming a ribbon along a. Analogous ribbons of $\mathrm{H}_{2} \mathrm{O}$ groups occur in epistolite (Sokolova and Hawthorne, 2004) and a seidozerite-supergroup mineral murmanite, $\mathrm{Na}_{4} \mathrm{Ti}_{4}\left(\mathrm{Si}_{2} \mathrm{O}_{7}\right)_{2} \mathrm{O}_{4}\left(\mathrm{H}_{2} \mathrm{O}\right)_{4}$ (Cámara et al., 2008). In zvyaginite, there is disorder of $\mathrm{Na}$ and $\square$ at the $A^{P}(2)$ site and $\mathrm{H}_{2} \mathrm{O}$ and $\square$ at the $W$ and $X_{\mathrm{A}}^{P}(2)$ sites, where Na at the $A^{P}(2)$ site (24\% occupancy) and an $\mathrm{H}_{2} \mathrm{O}$ group at the $X_{\mathrm{A}}^{P}(2)$ site (24\% occupancy) occur at short distances from an $\mathrm{H}_{2} \mathrm{O}$ group at the $W$ site ( $76 \%$ occupancy), 1.65 and $0.61 \AA$, respectively (Table 6, Fig. 4c). We suggest that two shortrange-order arrangements around the $A^{P}(2)$ site are possible: (1) the $A^{P}(2)$ and $X_{\mathrm{A}}^{P}(2)$ sites are locally occupied by $\mathrm{Na}$ and $\mathrm{H}_{2} \mathrm{O}$ and the $W$ site is vacant; (2) the $A^{P}(2)$ and $X_{\mathrm{A}}^{P}(2)$ sites are locally vacant and the $W$ site is occupied by $\mathrm{H}_{2} \mathrm{O}$ (Fig. 6).

We conclude that (1) the general topology of the crystal structure of zvyaginite described above is in accord with Pekov et al. (2014); (2) the stereochemistry of $\mathrm{Ti}, \mathrm{Zn}$ and $\mathrm{Na}$ in the TS block, especially for the $\mathrm{O}$ sheet, is different from that reported by Pekov et al. (2014); (3) doubling of the $t_{1}$ and $t_{2}$ translations of zvyaginite, $a_{\mathrm{zvy}}=10.769, b_{\mathrm{zvy}}=14.276 \AA$, 
a

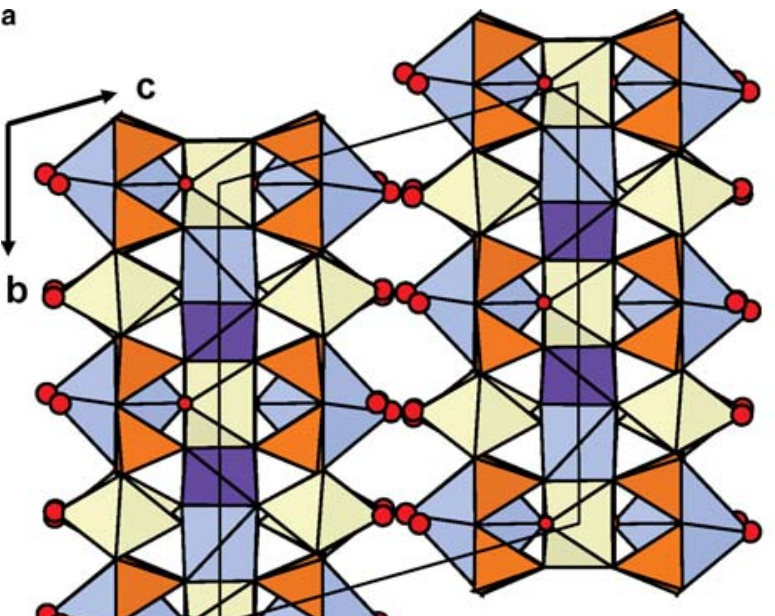

Zvyaginite

b

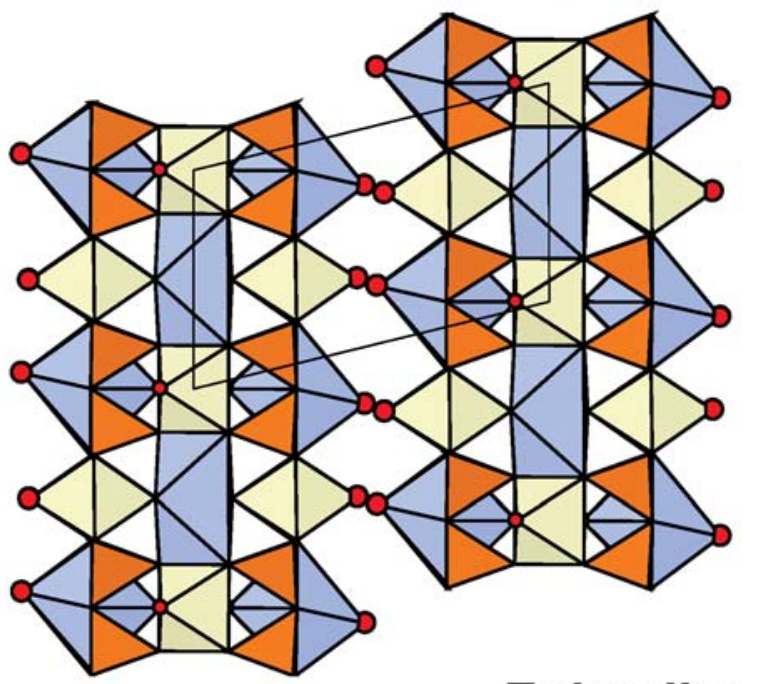

Epistolite

Fig. 5. A general view of the crystal structures of zvyaginite (a) and epistolite (b), cations (and polyhedra) at sites with occupancy less than $50 \%$ are not shown. Legend as in Fig. 4.

relative to those of epistolite: $a_{\mathrm{epi}}=5.460, b_{\mathrm{epi}}=$ $7.170 \AA$ (Fig. $4 b$ ), is due to order of $\mathrm{Zn}$ and $\mathrm{Na}$ along $\mathbf{a}\left(\mathbf{t}_{\mathbf{1}}\right)$ and $\mathbf{b}\left(\mathbf{t}_{\mathbf{2}}\right)$ in the $\mathrm{O}$ sheet of zvyaginite.

\section{The ideal structural formula of zvyaginite}

Above, we wrote the ideal structural formula of zvyaginite based on the occupancies of the cation and anion sites. Here, we write the ideal structural formula of zvyaginite in accord with Sokolova (2006); we use the general structural formula of the lamprophyllite-group mineral epistolite: $\mathrm{A}_{2}^{P} \mathrm{M}_{2}^{\mathrm{H}} \mathrm{M}_{4}^{\mathrm{O}}\left(\mathrm{Si}_{2} \mathrm{O}_{7}\right)_{2}\left(\mathrm{X}_{\mathrm{M}}^{\mathrm{O}}\right)_{2}\left(\mathrm{X}_{\mathrm{A}}^{\mathrm{O}}\right)_{2}\left(\mathrm{X}_{\mathrm{M}, \mathrm{A}}^{P}\right)_{4}$ where $\mathrm{A}^{P}$ are cations at the peripheral $(P)$ sites; $\mathrm{M}^{\mathrm{H}}$ and $\mathrm{M}^{\mathrm{O}}$ are cations of the $\mathrm{H}$ and $\mathrm{O}$ sheets; $\mathrm{X}^{\mathrm{O}}$ are anions of the $\mathrm{O}$ sheet; $\mathrm{X}_{\mathrm{M}}^{P}$ and $\mathrm{X}_{\mathrm{A}}^{P}$ are apical anions of the $\mathrm{M}^{\mathrm{H}}$ and $\mathrm{A}^{P}$ cations at the periphery of the TS block. In zvyaginite, $\mathrm{A}_{2}^{P}=\mathrm{A}^{P}(1)+\mathrm{A}^{P}(2)=\mathrm{Na}+\square=\mathrm{Na} \square$; $\mathrm{M}_{2}^{\mathrm{H}}=\mathrm{M}^{\mathrm{H}}(2)+\mathrm{M}^{\mathrm{H}}(1)=\mathrm{Nb}_{2} ; \quad \mathrm{M}_{4}^{\mathrm{O}}=\mathrm{NaZn} \square \mathrm{Ti} ;$ 
$\left(\mathrm{X}_{\mathrm{M}}^{\mathrm{O}}\right)_{2}=\mathrm{O}_{2} ;\left(\mathrm{X}_{\mathrm{A}}^{\mathrm{O}}\right)_{2}=(\mathrm{OH})_{2} ;\left(\mathrm{X}_{\mathrm{M}, \mathrm{A}}^{\mathrm{P}}\right)_{4}=\left(\mathrm{X}_{\mathrm{M}}^{\mathrm{P}}\right)_{2}+\mathrm{X}_{\mathrm{A}}^{\mathrm{P}}$ $+\mathrm{W}=\left(\mathrm{H}_{2} \mathrm{O}\right)_{2}+\mathrm{H}_{2} \mathrm{O}+\mathrm{H}_{2} \mathrm{O}=\left(\mathrm{H}_{2} \mathrm{O}\right)_{4}$. Hence, we write the ideal composition of the TS block in zvyaginite as follows:

$$
\begin{aligned}
& \mathrm{A}^{P}[\mathrm{Na} \square]^{\mathrm{M}^{\mathrm{H}}}\left[\mathrm{Nb}_{2}\right]^{\mathrm{M}^{\mathrm{O}}}[\mathrm{NaZn} \square \mathrm{Ti}]\left(\mathrm{Si}_{2} \mathrm{O}_{7}\right)_{2} \mathrm{X}^{\mathrm{O}}\left[\mathrm{O}_{2}(\mathrm{OH})_{2}\right] \\
& \mathrm{X}_{(\mathrm{M}, \mathrm{A})}^{P}\left[\left(\mathrm{H}_{2} \mathrm{O}\right)_{4}\right] \\
& \quad=\mathrm{Na} \square \mathrm{Nb}_{2} \mathrm{NaZn} \square \mathrm{Ti}\left(\mathrm{Si}_{2} \mathrm{O}_{7}\right)_{2} \mathrm{O}_{2}(\mathrm{OH})_{2}\left(\mathrm{H}_{2} \mathrm{O}\right)_{4}, \\
& Z=4 .
\end{aligned}
$$

\section{Summary}

(1) Electron-microprobe analysis of zvyaginite from the type locality, Mt. Malyi Punkaruaiv, Lovozero alkaline massif, Kola Peninsula, Russia gave a higher $\mathrm{Na}_{2} \mathrm{O}$ content than that reported previously: 7.10 vs. 4.74 wt.\% (Pekov et al., 2014). The empirical and ideal formulae of zvyaginite have been revised as follows: $\left(\mathrm{Na}_{0.75} \mathrm{Ca}_{0.09} \mathrm{~K}_{0.04}\right.$ $\left.\square_{1.12}\right)_{\Sigma 2}\left(\mathrm{Na}_{1.12} \mathrm{Zn}_{0.88} \mathrm{Mn}_{0.17} \mathrm{Fe}_{0.04}^{2+} \square_{0.79}\right)_{\Sigma 3}\left(\mathrm{Nb}_{1.68}\right.$ $\left.\mathrm{Ti}_{1.25} \mathrm{Al}_{0.07}\right)_{\Sigma 3}\left(\mathrm{Si}_{4.03} \mathrm{O}_{14}\right) \mathrm{O}_{2} \quad\left[(\mathrm{OH})_{1.11} \mathrm{~F}_{0.89}\right]_{\Sigma 2}$ $\left(\mathrm{H}_{2} \mathrm{O}\right)_{4}$ and $\mathrm{Na}_{2} \mathrm{ZnTiNb}_{2}\left(\mathrm{Si}_{2} \mathrm{O}_{7}\right)_{2} \mathrm{O}_{2}(\mathrm{OH})_{2}\left(\mathrm{H}_{2} \mathrm{O}\right)_{4}$, $Z=4$ [cf. idealized formula of Pekov et al. (2014):

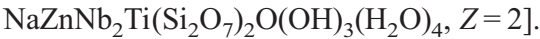

(2) The crystal structure of zvyaginite has been revised: space group $C \overline{1}, a=10.769(2), b=14.276(3)$, $c=12.101(2) \quad \AA, \quad \alpha=105.45(3), \quad \beta=95.17(3)$, $\gamma=90.04(3)^{\circ}, \quad V=1785.3(3.2) \AA^{3}, \quad R_{1}=9.23 \%$, $\mathrm{Z}=4$. The general topology of the crystal structure is in accord with Pekov et al. (2014): it is an array of TS blocks connected via hydrogen bonds between $\mathrm{H}_{2} \mathrm{O}$ groups. However the stereochemistry of the TS block is different from that of Pekov et al. (2014): the choice of a new origin in the crystal structure of zvyaginite reveals order of $\mathrm{Zn}$ and $\mathrm{Na}$ in the $\mathrm{O}$ sheet of the TS block of the composition $\left[\mathrm{NaZn} \square \mathrm{TiO}_{2}(\mathrm{OH})_{2}\right]^{1+}$ and order of $\mathrm{Na}$ and $\square$ in the two $\mathrm{H}$ sheets of the composition $\left[\mathrm{Na} \square \mathrm{Nb}_{2}\right.$ $\left.\left(\mathrm{Si}_{2} \mathrm{O}_{7}\right)_{2}\left(\mathrm{H}_{2} \mathrm{O}\right)_{4}\right]^{1-}$. The structure-refinement results are in accord with the chemical analysis.

(3) Zvyaginite, ideally $\mathrm{Na} \square \mathrm{Nb}_{2} \mathrm{NaZn} \square \mathrm{Ti}$ $\left(\mathrm{Si}_{2} \mathrm{O}_{7}\right)_{2} \mathrm{O}_{2}(\mathrm{OH})_{2}\left(\mathrm{H}_{2} \mathrm{O}\right)_{4}$, is a TS-block mineral of the lamprophyllite group (seidozerite supergroup) where $\mathrm{Ti}+\mathrm{Nb}+\mathrm{Fe}^{3+}+\mathrm{Mg}=3$ apfu. The crystal structure of zvyaginite is of the same topology as that of epistolite, $(\mathrm{Na} \square) \mathrm{Nb}_{2} \mathrm{Na}_{3} \mathrm{Ti}_{(}\left(\mathrm{Si}_{2} \mathrm{O}_{7}\right)_{2} \mathrm{O}_{2}(\mathrm{OH})_{2}$ $\left(\mathrm{H}_{2} \mathrm{O}\right)_{4}$. Zvyaginite is a $\mathrm{Zn}$-bearing and Na-poor analogue of epistolite.

(4) Epistolite and zvyaginite are related by the following substitution in the $\mathrm{O}$ sheet of the TS-block: $\left(\mathrm{Na}_{2}^{+}\right)_{\text {epi }} \leftrightarrow \mathrm{Zn}_{\mathrm{zvy}}^{2+}+\square_{\mathrm{zvy}}$. The doubling of the $t_{1}$ and $t_{2}$ translations of zvyaginite, $a_{\mathrm{zvy}}=10.769, b_{\mathrm{zvy}}=$

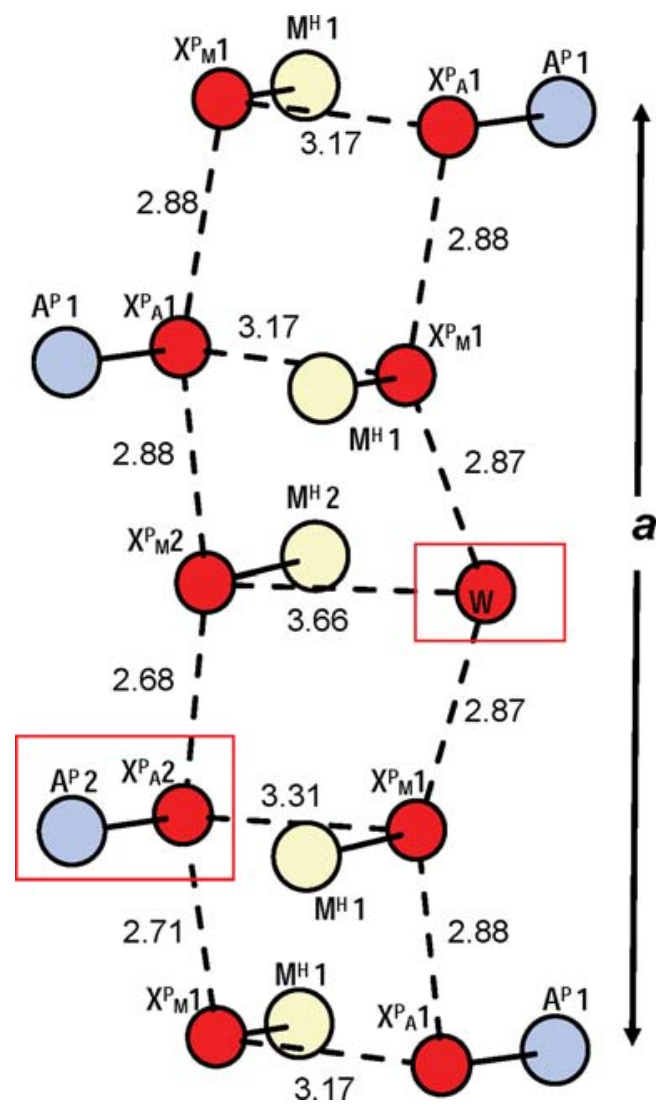

FIG. 6. A general scheme of possible hydrogen bonding in zvyaginite. $\mathrm{O}$ atoms of $\mathrm{H}_{2} \mathrm{O}$ groups at the $X^{P}$ and $W$ sites are shown as large red spheres, [8]-coordinated $\mathrm{Na}$ atoms at the $A^{P}$ sites are shown as blue spheres and [6]coordinated $\mathrm{Nb}$ atoms at the $M^{\mathrm{H}}$ sites are shown as yellow spheres; bonds $\mathrm{Nb}-\mathrm{O}\left(\mathrm{H}_{2} \mathrm{O}\right)$ and $\mathrm{Na}-\mathrm{O}\left(\mathrm{H}_{2} \mathrm{O}\right)$ are shown as solid black lines; possible directions of hydrogen bonds are shown as dashed black lines and their lengths are given in $\AA$. Red rectangles show possible short-range-order arrangements around the $A^{P}(2)$ site: (left) SRO 24\%: $\mathrm{A}^{P}(2)=\mathrm{Na}, \mathrm{X}^{P}(2)=\mathrm{H}_{2} \mathrm{O}, \mathrm{W}=\square$; (right) SRO 76\%: $\mathrm{A}^{P}(2)=\square, \mathrm{X}^{P}(2)=\square, \mathrm{W}=\mathrm{H}_{2} \mathrm{O}$.

14.276 A, relative to those of epistolite: $a_{\mathrm{epi}}=5.460$, $b_{\text {epi }}=7.170 \AA$, is due to the order of $\mathrm{Zn}$ and $\mathrm{Na}$ along $\mathbf{a}\left(\mathbf{t}_{1}\right)$ and $\mathbf{b}\left(\mathbf{t}_{\mathbf{2}}\right)$ in the $\mathrm{O}$ sheet of zvyaginite.

(5) The TEM investigation revealed a band structure characterized by the alternation of defectfree bands and defect-rich domains along the $<001>$ direction. The defect-bearing bands, in turn, exhibit interleaving of $\{001\}$ lamellae extended many hundreds of nanometres along the $<110>$ direction, a few tens of nanometres along the $<001>$ and very few tens of nanometres along the $<\overline{1} 10>$ direction. 
Khomyakov (1995) coined the name transformation minerals for vuonnemite, ideally $\mathrm{Na}_{6} \mathrm{Na}_{2} \mathrm{Nb}_{2} \mathrm{Na}_{3} \mathrm{Ti}\left(\mathrm{Si}_{2} \mathrm{O}_{7}\right)_{2}\left(\mathrm{PO}_{4}\right)_{2} \mathrm{O}_{2}(\mathrm{OF}) \quad($ Ercit et al., 1998) and epistolite, ideally $(\mathrm{Na} \square)$ $\mathrm{Nb}_{2} \mathrm{Na}_{3} \mathrm{Ti}\left(\mathrm{Si}_{2} \mathrm{O}_{7}\right)_{2} \mathrm{O}_{2}(\mathrm{OH})_{2}\left(\mathrm{H}_{2} \mathrm{O}\right)_{4}$, meaning that epistolite is formed by ion-exchange from vuonnemite, a precursor mineral of related structure. The interleaving of well-crystalline zvyaginite with lamellae of poor crystallinity and undulating lattice planes supports the idea of Pekov et al. (2014) that epistolite and zvyaginite are transformation minerals, too.

\section{Acknowledgements}

We are grateful to an anonymous reviewer and Associate Editor Peter Leverett for useful comments. We thank Mark A. Cooper for collection of singlecrystal X-ray data for three zvyaginite crystals. ES acknowledges financial support by a Canada Research Chair in Crystallography and Mineralogy to FCH. FCH acknowledges support by a Canada Research Chair in Crystallography and Mineralogy and by a Discovery Grant from the Natural Sciences and Engineering Research Council of Canada, and by Innovation Grants from the Canada Foundation for Innovation.

\section{References}

Aksenov, S.M., Rastsvetaeva, R.K. and Chukanov, N.V. (2014) The crystal structure of emmerichite $\mathrm{Ba}_{2} \mathrm{Na}_{3}$ $\mathrm{Fe}^{3+} \mathrm{Ti}_{2}\left(\mathrm{Si}_{2} \mathrm{O}_{7}\right)_{2} \mathrm{O}_{2} \mathrm{~F}_{2}$, a new lamprophyllite-group mineral. Zeitschrift für Kristallographie, 229, 1-7.

Andrade, M.B., Yang, H., Downs, R.T., Färber, G., Contreira Filho, R.R., Evans, S.H., Loehn, C.W. and Schumer, B.N. (2017) Fluorlamprophyllite, $\mathrm{Na}_{3}(\mathrm{SrNa})$ $\mathrm{Ti}_{3}\left(\mathrm{Si}_{2} \mathrm{O}_{7}\right) \mathrm{O}_{2} \mathrm{~F}_{2}$, a new mineral from Poços de Caldas alkaline massif, Morro do Serrote, Mines Gerais, Brazil. Mineralogical Magazine, https://doi.org/10.1180/ minmag.2017.081.027

Brown, I.D. (1981) The bond-valence method: an empirical approach to chemical structure and bonding. Pp. 1-30 in: Structure and Bonding in Crystals II (M. O'Keeffe and A. Navrotsky, editors). Academic Press, New York.

Cámara, F. and Sokolova, E. (2007) From structure topology to chemical composition. VI. Titanium silicates: the crystal structure and crystal chemistry of bornemanite, a group III Ti-disilicate mineral. Mineralogical Magazine, 71, 593-610.

Cámara, F. and Sokolova, E. (2009) From structure topology to chemical composition. X. Titanium silicates: the crystal structure and crystal chemistry of nechelyustovite, a group III Ti-disilicate mineral. Mineralogical Magazine, 73, 887-897.
Cámara, F., Sokolova, E., Hawthorne, F.C. and Abdu, Y. (2008) From structure topology to chemical composition. IX. Titanium silicates: revision of the crystal chemistry of lomonosovite and murmanite, Group-IV minerals. Mineralogical Magazine, 72, 1207-1228.

Cámara, F., Sokolova, E. and Hawthorne, F.C. (2012) Kazanskyite, BaTiNbNa $3 \mathrm{Ti}\left(\mathrm{Si}_{2} \mathrm{O}_{7}\right)_{2} \mathrm{O}_{2}(\mathrm{OH})_{2}\left(\mathrm{H}_{2} \mathrm{O}\right)_{4}$, a Group-III Ti-disilicate mineral from the Khibiny alkaline massif, Kola Peninsula, Russia: description and crystal structure. Mineralogical Magazine, 76, 473-492.

Cámara, F., Sokolova, E., Abdu, Y.A. and Hawthorne, F.C. (2014) Saamite, $\mathrm{Ba} \square \mathrm{TiNbNa}{ }_{3} \mathrm{Ti}\left(\mathrm{Si}_{2} \mathrm{O}_{7}\right)_{2} \mathrm{O}_{2}(\mathrm{OH})_{2}$ $\left(\mathrm{H}_{2} \mathrm{O}\right)_{2}$, a Group-III Ti-disilicate mineral from the Khibiny alkaline massif, Kola Peninsula, Russia: description and crystal structure. The Canadian Mineralogist, 52, 745-761.

Chukanov, N.V., Pekov, I.V., Rastsvetaeva, R.K., Aksenov, S.M., Zadov, A.E., Van, K.V., Blass, G., Schüller, W. and Ternes, B. (2012) Lileyite, $\mathrm{Ba}_{2}(\mathrm{Na}$, $\mathrm{Fe}, \mathrm{Ca})_{3} \mathrm{MgTi}_{2}\left(\mathrm{Si}_{2} \mathrm{O}_{7}\right)_{2} \mathrm{O}_{2} \mathrm{~F}_{2}$, a new lamprophyllitegroup mineral from the Eifel volcanic area, Germany. European Journal of Mineralogy, 24, 181-188.

Ercit, T.S., Cooper, M.A. and Hawthorne, F.C. (1998) The crystal structure of vuonnemite, $\mathrm{Na}_{11} \mathrm{Ti}^{4+}$ $\mathrm{Nb}_{2}\left(\mathrm{Si}_{2} \mathrm{O}_{7}\right)_{2}\left(\mathrm{PO}_{4}\right)_{2} \mathrm{O}_{3}(\mathrm{~F}, \mathrm{OH})$, a phosphate-bearing sorosilicate of the lomonosovite group. The Canadian Mineralogist, 37, 1311-1320.

Khomyakov, A.P. (1995) Mineralogy of Hyperagpaitic Alkaline Rocks. Clarendon Press, Oxford, UK.

Krivovichev, S.V., Armbruster, T., Yakovenchuk, V.N., Pakhomovsky, Ya.A. and Men'shikov, Yu. P. (2003) Crystal structures of lamprophyllite-2 $M$ and lamprophyllite- $2 O$ from the Lovozero alkaline massif, Kola peninsula, Russia. European Journal of Mineralogy, 15, 711-718.

Lykova, I.S., Pekov, I.V., Zubkova, N.V., Yapaskurt, V.O., Chervonnaya, N.A., Zolotarev, A.A. and Giester, G. (2015) Crystal chemistry of cation-exchanged forms of epistolite-group minerals. Part II. Vigrishinite and Zn-exchanged murmanite. European Journal of Mineralogy, 27, 669-682.

Pekov, I.V., Britvin, S.N., Zubkova, N.V., Chukanov, N.V., Bryzgalov, I.A., Lykova, I.S., Belakovskiy, D.I. and Pushcharovsky, D.Yu. (2013) Vigrishinite, $\mathrm{Zn}_{2} \mathrm{Ti}_{4-x}$ $\mathrm{Si}_{4} \mathrm{O}_{14}\left(\mathrm{OH}, \mathrm{H}_{2} \mathrm{O}, \square\right)_{8}$, a new mineral from the Lovozero alkaline complex, Kola Peninsula, Russia. Geology of Ore Deposits, 55, 575-586.

Pekov, I.V., Lykova, I.S., Chukanov, N.V., Yapaskurt, V. O., Belakovskiy, D.I., Zolotarev Jr, A.A. and Zubkova, N.V. (2014) Zvyaginite, $\mathrm{NaZnNb}_{2} \mathrm{Ti}_{2}\left(\mathrm{Si}_{2} \mathrm{O}_{7}\right)_{2} \mathrm{O}(\mathrm{OH}$, F) ${ }_{3}\left(\mathrm{H}_{2} \mathrm{O}\right)_{4+x}(x<1)$, a new mineral of the epistolite group from the Lovozero alkaline pluton, Kola Peninsula, Russia. Geology of Ore Deposits, 56, 644-656. 


\section{E. SOKOLOVA ETAL.}

Pouchou, J.L. and Pichoir, F. (1985) "PAP" $\varphi(\rho Z)$ procedure for improved quantitative microanalysis. Pp. 104-106 in: Microbeam Analysis (J.T. Armstrong, editor). San Francisco Press, San Francisco, California, USA.

Rastsvetaeva, R.K. and Chukanov, N.V. (1999) Crystal structure of a new high-barium analogue of lamprophyllite with a primitive unit cell. Doklady Chemistry, 368, 228-231.

Shannon, R.D. (1976) Revised effective ionic radii and systematic studies of interatomic distances in halides and chalcogenides. Acta Crystallographica, A32, 751-767.

Sheldrick, G.M. (2008) A short history of SHELX. Acta Crystallographica, A64, 112-122.

Sokolova, E. (2006) From structure topology to chemical composition. I. Structural hierarchy and stereochemistry in titanium disilicate minerals. The Canadian Mineralogist, 44, 1273-1330.

Sokolova, E. and Cámara, F. (2007) From structure topology to chemical composition. II. Titanium silicates: revision of the crystal structure and chemical formula of delindeite. The Canadian Mineralogist, 45, 1247-1261.

Sokolova, E. and Cámara, F. (2008) From structure topology to chemical composition. III. Titanium silicates: crystal chemistry of barytolamprophyllite. The Canadian Mineralogist, 46, 403-412.

Sokolova, E. and Cámara, F. (2013) From structure topology to chemical composition. XVI. New developments in the crystal chemistry and prediction of new structure topologies for titanium disilicate minerals with the TS block. The Canadian Mineralogist, 51, 861-891.

Sokolova, E. and Cámara, F. (2016) From structure topology to chemical composition. XXI. Understanding the crystal chemistry of barium in TS-block minerals. The Canadian Mineralogist, 54, 79-95.

Sokolova, E. and Cámara, F. (2017) The seidozerite supergroup of TS-block minerals: nomenclature and classification, with change of the following names rinkite to rinkite-(Ce), mosandrite to mosandrite-(Ce), hainite to hainite-(Y) and innelite-1 $T$ to innelite-1 $A$. Mineralogical Magazine, 81, 1457-1484.

Sokolova, E. and Hawthorne, F.C. (2004) The crystal chemistry of epistolite. The Canadian Mineralogist, 42, 797-806.

Sokolova, E. and Hawthorne, F.C. (2008) From structure topology to chemical composition. IV. Titanium silicates: the orthorhombic polytype of nabalamprophyllite from Lovozero massif, Kola Peninsula, Russia. The Canadian Mineralogist, 46, 1323-1331.

Sokolova, E., Cámara, F. and Hawthorne, F.C. (2011) From structure topology to chemical composition. XI. Titanium silicates: crystal structures of innelite- $1 T$ and innelite- $2 M$ from the Inagli massif, Yakutia, Russia and the crystal chemistry of innelite. Mineralogical Magazine, 75, 2495-2518.

Wilson, A.J.C. (editor) (1992) International Tables for Crystallography. Volume C: Mathematical, physical and chemical tables. Kluwer Academic Publishers, Dordrecht, The Netherlands. 